\title{
Influence of desialylation of caseinomacropeptide on the denaturation and aggregation of whey proteins
}

\author{
Sophie J. Gaspard, ${ }^{1,2}$ Anne V. Sunds, ${ }^{3}$ Lotte B. Larsen, ${ }^{3}$ Nina A. Poulsen, ${ }^{3}$ James A. O'Mahony, ${ }^{2}$ Alan L. Kelly, ${ }^{2}$ \\ and André Brodkorb ${ }^{1 *}$ \\ ${ }^{1}$ Teagasc Food Research Centre, Moorepark, Fermoy, Co. Cork, P61 C996, Ireland \\ ${ }^{2}$ School of Food and Nutritional Sciences, University College Cork, T12 YN60, Ireland \\ ${ }^{3}$ Department of Food Science, Faculty of Technical Sciences, Aarhus University, 8200 Aarhus N Denmark
}

\section{ABSTRACT}

The effect of the addition of caseinomacropeptide (CMP) or desialylated CMP on the heat-induced denaturation and aggregation of whey proteins was investigated in the $\mathrm{pH}$ range 3 to 7 after heating at $80^{\circ} \mathrm{C}$ for $30 \mathrm{~min}$. The rate and temperature of denaturation, the extent of aggregation, and the changes in secondary structure of the whey proteins heated in presence of CMP or desialylated CMP were measured. The sialic acid bound to CMP favored the denaturation and aggregation of whey proteins when the whey proteins were oppositely charged to $\mathrm{CMP}$ at $\mathrm{pH} 4$. A transition occurred at $\mathrm{pH} 6$, below which the removal of sialic acid enhanced the stabilizing properties of CMP against the denaturation and aggregation of the whey proteins. At $\mathrm{pH}>6$, the interactions between desialylated CMP and the whey proteins led to more extensive denaturation and aggregation. Sialic acid bound to CMP influenced the denaturation and aggregation behavior of whey proteins in a $\mathrm{pH}$-dependent manner, and this should be considered in future studies on the heat stability of such systems containing CMP.

Key words: caseinomacropeptide, sialic acid, whey protein, denaturation, aggregation

\section{INTRODUCTION}

Bovine whey proteins are known for their nutritional and bioactive properties, which make them ideal ingredients for nutritional beverages such as infant milk formula and protein drinks for athletes and the elderly. However, these ingredients need to be able to withstand thermal treatments such as pasteurization and ultra-high temperature processing, applied for reasons

Received October 22, 2019.

Accepted January 24, 2020.

*Corresponding author: andre.brodkorb@teagasc.ie of microbiological safety control. Whey proteins are thermolabile and form soluble aggregates, undesirable large visible gel particles or continuous gel networks, depending on the conditions of heat treatment.

Bovine caseinomacropeptide (CMP), commonly referred as glycomacropeptide when glycosylated, is a 64-AA peptide resulting from the enzymatic cleavage of $\kappa$-casein into 2 peptides (CMP and para-k-casein) and is very heat stable. Glycosylated proteins, such as CMP, present bioactive properties specific to their carbohydrate side chains, sometimes also referred to as prosthetic groups (Nagel et al., 1992). N-Acetyl neuraminic acid (NeuAc) is the most abundant member of the sialic acid family in mammalians and is responsible for many of the bioactive properties of bovine CMPfor example, the promotion of gut microbial growth, the improvement of learning abilities, and the modulation of the immune system response (Brody, 2000; Thomä-Worringer et al., 2006; O'Riordan et al., 2014). Among other functions, sialic acids play roles in the stabilization of cells and proteins and participate in the transport of positively-charged ions (Traving and Schauer, 1999; Cases et al., 2003; Varki, 2008).

Caseinomacropeptide represents up to $25 \%$ (wt/wt) of the total protein in cheese whey (Thomä-Worringer et al., 2006). In this fraction, around 50\% of CMP is glycosylated, with the peptide containing up to 6 glycosylation and 3 phosphorylation sites in its $\mathrm{C}$ terminal part (Figure 1A). In mature cow milk, NeuAc is generally located at the end of a glycosylation chain, which, apart from NeuAc, contains galactose and $\mathrm{N}$ acetyl galactosamine, organized from monosaccharide to tetrasaccharide (Saito and Itoh, 1992). Because of its carboxylic functional group (Figure 1B), NeuAc exhibits a $\mathrm{p} K_{\mathrm{a}}$ of 2.6 and lowers the overall isoelectric point (pI) of the glycoproteins. The estimated pI of $\kappa$-casein, based on the primary sequence, is 5.93; phosphorylation lowers the pI to 5.6, whereas glycosylation lowers the pI to 3.5 (Huppertz, 2013). The pI of glycosylated and non-glycosylated CMP were reported to be 3.2 
A

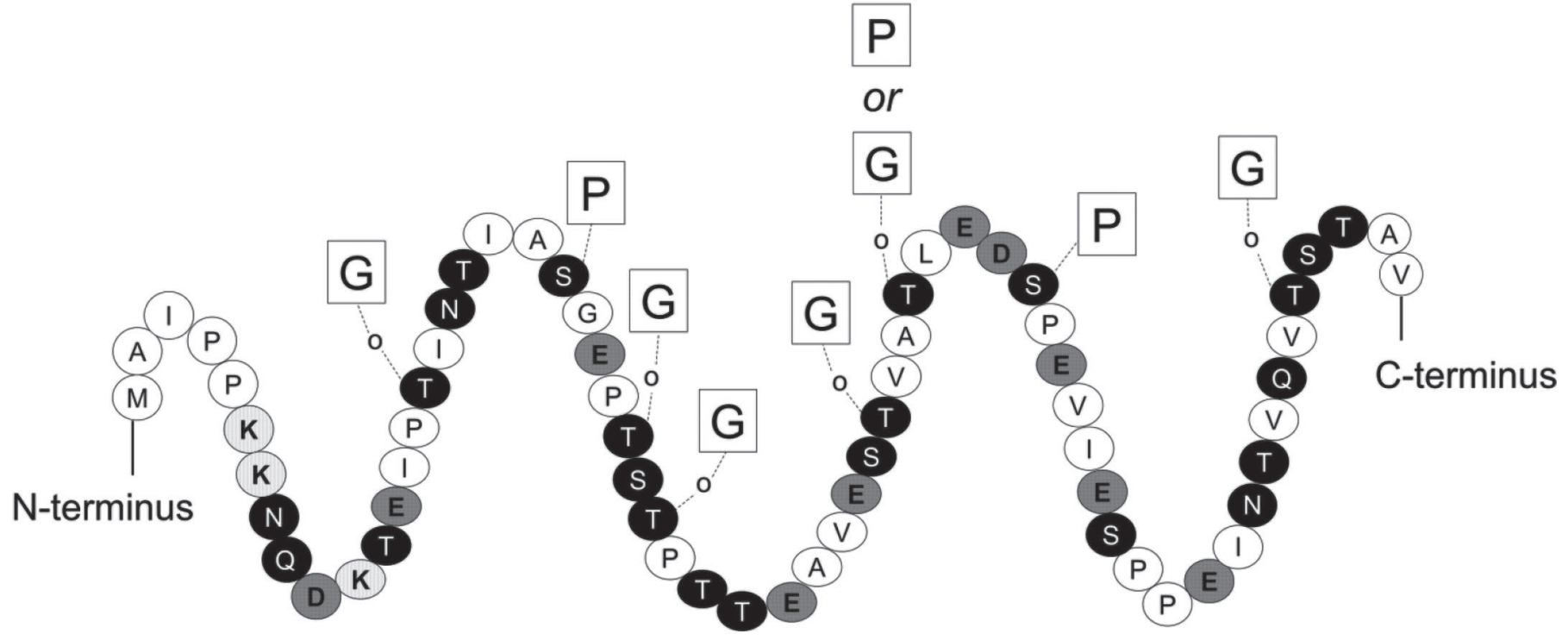

$\mathrm{B}$

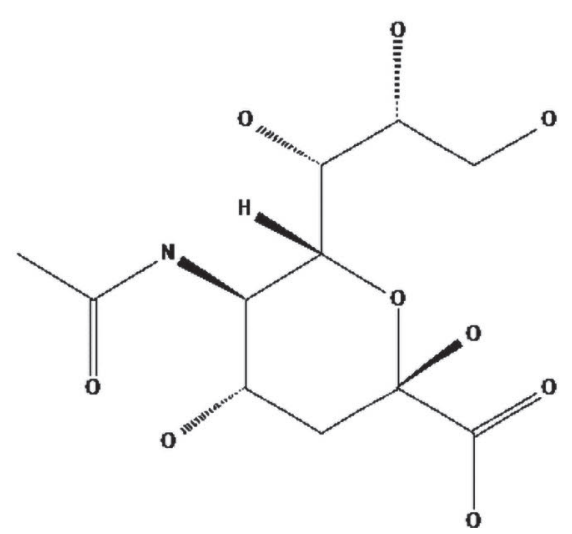

Figure 1. (A) Amino acid sequence of caseinomacropeptide (CMP), derived from $\kappa$-casein A, with potential sites for post-translational modifications; potential glycosylation site (circle linked to G); potential phosphorylation site (circle linked to P). The amino acids with non-polar (open circle), polar (filled circle), negatively charged (dark gray circle), and positively charged side chains (light gray circle) are also indicated in the figure, as reviewed by Holland (2008). (B) Two-dimensional structure of $N$-acetyl- $\beta$-D-neuraminic acid (PubChem CID: 445063).

and 4.2, respectively (Kreuß et al., 2009). The degree of phosphorylation and glycosylation of CMP varies widely and is illustrated by multiple peaks in the elution profiles of reversed-phase (RP)-HPLC (Thomä et al., 2006) and liquid chromatography-MS (Sunds et al., 2019), as well as by separation of CMP spots by 2-dimensional electrophoretic analysis (Le et al., 2016). The negative charges of the charged amino acid residues, the post-translational modifications at neutral $\mathrm{pH}$, and the disordered structure of the peptide all result in a very hydrophilic and heat-stable polypeptide. However, NeuAc is sensitive to acid and heat treatment (Siegert et al., 2012; Kilic-Akyilmaz and Karimidastjerd, 2018).
Therefore, not all CMP contains the same amount of NeuAc, due to heat-induced losses (Taylor and Woonton, 2009).

These properties can improve the solubility of other proteins when heated in the presence of CMP. The post-translational modifications of the heat-stable proteins $\alpha_{S^{-}}, \beta$-, and $\kappa$-casein are thought to be involved in the control of the aggregation of whey proteins during heat treatment, by limiting the size of aggregates or the extent of aggregation (Morgan et al., 2005; Guyomarc'h et al., 2009; Koudelka et al., 2009; Kehoe and Foegeding, 2014). In addition, Doi et al. (1981) showed a correlation between degree of glycosylation of $\kappa$-casein 
and improved heat stability of $\beta$-LG. Croguennec et al. (2014) studied the effect of CMP on the denaturation and aggregation of whey proteins and demonstrated that CMP increased the rate of denaturation of $\beta-\mathrm{LG}$ via hydrophobic and electrostatic interactions at $\mathrm{pH}$ 4.0 and 6.7. However, it could limit the aggregation of $\beta-\mathrm{LG}$ at $\mathrm{pH} 6.7$ due to the negative charges carried by $\mathrm{CMP}$ around the neutral $\mathrm{pH}$. Therefore, it is possible that the glycosylation of CMP is involved in the control of aggregation of whey proteins.

To the authors' knowledge, the effect of the sialic acid content of CMP on the denaturation and aggregation of a mixture of $\beta-\mathrm{LG}$ and $\alpha-\mathrm{LA}$, as in whey protein isolate (WPI), has not yet been the subject of any studies. The aim of this study is to bring new insights to the effect of the negatively-charged NeuAc on the denaturation and aggregation behavior of $\beta-\mathrm{LG}$ and $\alpha$-LA in WPI across a wide $\mathrm{pH}$ range (3 to 7 ) during heat treatment $\left(80^{\circ} \mathrm{C}\right.$ for 2 to $\left.30 \mathrm{~min}\right)$, with a view to developing strategies for enhancement of the heat stability of whey protein systems.

\section{MATERIALS AND METHODS}

\section{Materials}

All reagents were purchased from Sigma-Aldrich (St. Louis, MO) unless stated otherwise. Denatured whey proteins were removed from native whey proteins by isoelectric precipitation. Briefly, a solution of $10 \%$ (wt/ vol) WPI (Davisco Bipro, Eden Prairie, MN) was rehydrated in Milli-Q water (Millipore, Billerica, MA), heated at $40^{\circ} \mathrm{C}$ for $2 \mathrm{~h}$ and stirred overnight at $4^{\circ} \mathrm{C}$. The $\mathrm{pH}$ of the solution was adjusted to 4.6 , and the solution was centrifuged at $4,000 \times g$ for $40 \mathrm{~min}$ to separate aggregated material from soluble whey proteins. The supernatant, containing the native whey proteins, was adjusted to $\mathrm{pH} 7.0$ and dialyzed against $10 \mathrm{mM}$ sodium phosphate (pH 7.0) for $24 \mathrm{~h}$ with 2 changes of buffer, then for $24 \mathrm{~h}$ in distilled water with 2 changes of water. The dialyzed solutions were freeze-dried. The protein content was measured via RP-HPLC, using a modification of the method of Beyer and Kessler (1989).

A solution of CMP (Lacprodan c-glycomacropeptide-20, Arla Foods Ingredients, Viby J, Denmark) was enzymatically desialylated, following the method initially described by Villumsen et al. (2015) and modified by Sunds et al. (2019). Briefly, the sialidase was added in a ratio of 1:57,000 (wt/wt) to the protein solution rehydrated at $7 \%$ at $\mathrm{pH} 5.8$. The sample was incubated at $37^{\circ} \mathrm{C}$ overnight and freeze-dried.

The desialylation of CMP resulted in a shift in its pI from 3.0 for the untreated CMP to around 3.7 for the desialylated CMP (d-CMP) after analysis via 2-dimen- sional SDS-PAGE, as analyzed and reported elsewhere on the same batch of powder (Sunds et al., 2019). The chromatogram presented in Figure 2A shows the effect of desialylation on the chromatogram of CMP and dCMP. The CMP and d-CMP powders were rehydrated, dialyzed, and freeze-dried following the same process as for the WPI powders.

\section{Reconstitution}

Mixtures of WPI with CMP or d-CMP were rehydrated in Milli-Q water. The concentration of whey protein in the mixtures was $0.5 \%$ (wt/vol). However, the protein content of the freeze-dried CMP and d-CMP powders could not be accurately estimated through the Kjeldahl method, due to the unknown nitrogento-protein conversion factor of CMP and d-CMP used in this study, which varies from 6.71 to 7.37 depending on the variant and as a function of the degree of glycosylation (Karman and Van Boekel, 1986). Attempts to quantify CMP and d-CMP through RP-HPLC, by measuring the sum of the peak areas at $214 \mathrm{~nm}$, show that both powders contained the peptide in comparable amounts. Therefore, the CMP or d-CMP powders were added to the whey protein sample at a concentration of $0.5 \%$ (weight of CMP or d-CMP powder by volume). As control samples, solutions of 0.5 and $1 \%$ (wt/vol) whey protein were rehydrated in Milli-Q water.

Higher protein concentrations were required for the differential scanning calorimetric (DSC) and the Fourier-transform infrared spectroscopy (FTIR) measurements. Hence, solutions of $2.5 \%$ (wt/vol) whey proteins were also prepared with CMP or d-CMP. As control samples, solutions of 2.5 and $5 \%$ (wt/vol) whey proteins were rehydrated in Milli-Q water.

\section{Heating of Protein Solutions}

For the measurement of the degree of denaturation of the whey proteins, the $\zeta$-potential, the molecular weight distribution, the turbidity measurement, and the microscopy images, the $\mathrm{pH}$ of the 5 -mL solutions was adjusted to $3,4,5,6$, and 7 and subsequently heated in a water bath at $80^{\circ} \mathrm{C}$, and aliquots of $0.7 \mathrm{~mL}$ were removed at 2, 5, 10, 15, 20, and 30 min for analysis. The aliquots were immediately cooled to room temperature.

For the FTIR measurement, the $\mathrm{pH}$ of the samples was adjusted to $4,5,6$, or 7 and a volume of $200 \mu \mathrm{L}$ was heated for $30 \mathrm{~min}$ at $80^{\circ} \mathrm{C}$ in a water bath. The samples were heated for only $5 \mathrm{~min}$ at $\mathrm{pH} 5$ to avoid gelling of the samples. The samples were immediately cooled to room temperature. For the DSC measurement, the $\mathrm{pH}$ of the samples was adjusted to $4,5,6$, or 7 , and samples were heated in the equipment as described below. 
A

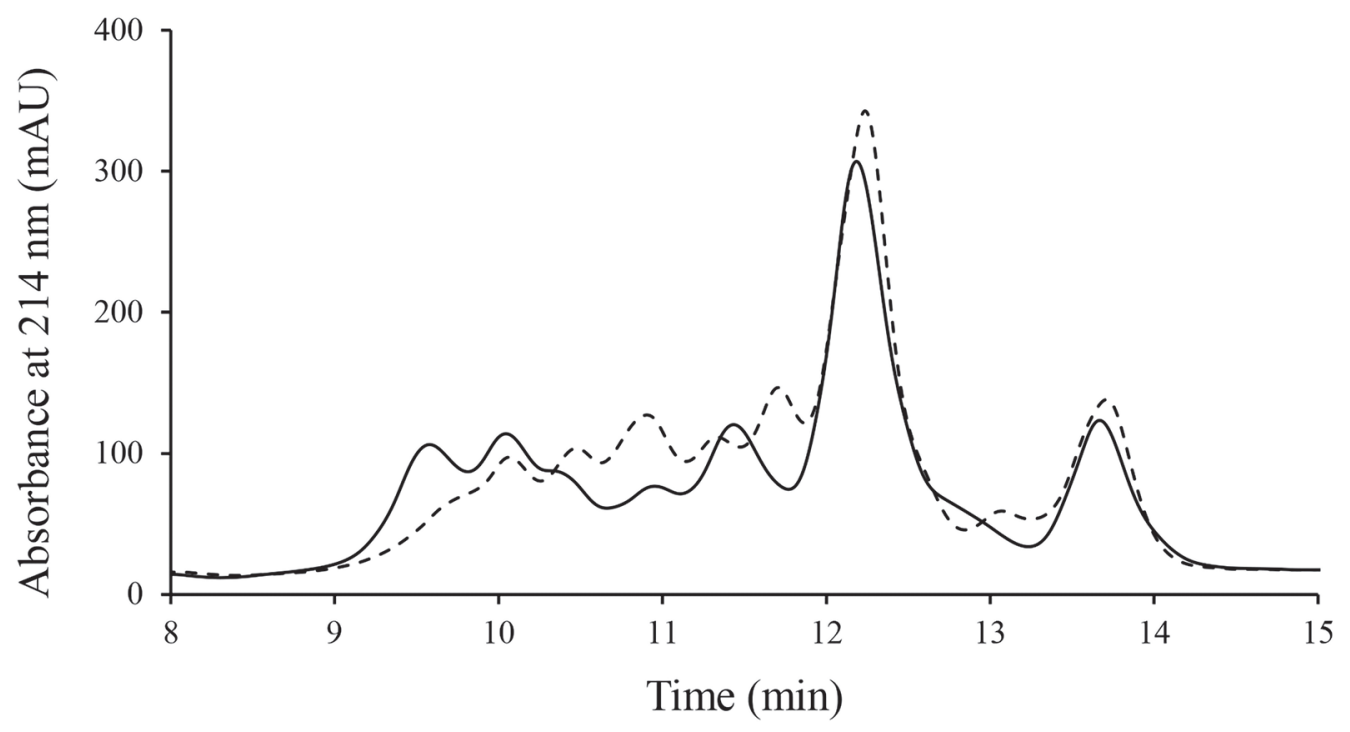

B

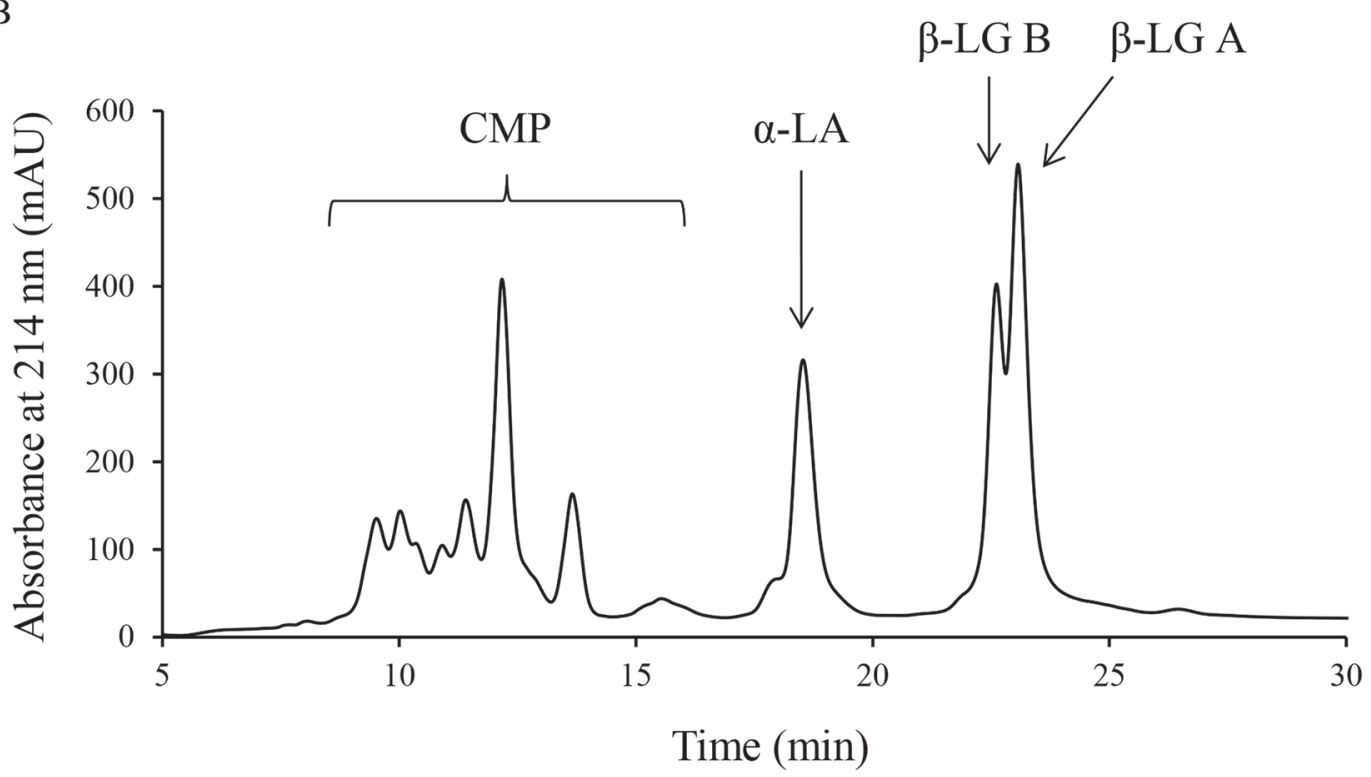

Figure 2. Chromatogram of (A) solutions of caseinomacropeptide (CMP; solid line) and desialylated CMP (dashed line) and (B) a mixture of CMP and whey proteins, containing $\alpha$-LA and $\beta$-LG A and B, resolved using reversed-phase HPLC.

\section{Degree of Denaturation}

The residual content of native whey proteins after heating was measured via RP-HPLC. The samples were diluted in a sodium acetate and acetic acid buffer at $\mathrm{pH} 4.6$ with a ratio 1:1 to precipitate all denatured and subsequently aggregated proteins (Tolkach et al., 2005; Kehoe et al., 2011). The samples were centrifuged at $14,000 \times g$ for $30 \mathrm{~min}$ at $20^{\circ} \mathrm{C}$, and the supernatant was filtered through $0.45-\mu \mathrm{m}$ hydrophilic filters (PES membrane filter type, Sartorius, Göttingen, Germany).
A C5 PolymerX RP1 column from Phenomenex (Torrance, CA) was used. Buffer A contained $0.1 \%$ (vol/ vol) TFA in water, and buffer B contained $90 \%$ (vol/ vol) $\mathrm{ACN}$ and $0.1 \%$ (vol/vol) TFA. The gradient of buffer B was $20 \%$ for $3 \mathrm{~min}, 20$ to $40 \%$ in $10 \mathrm{~min}, 40$ to $60 \%$ in $20 \mathrm{~min}, 60$ to $100 \%$ in $2 \mathrm{~min}, 100 \%$ for $5 \mathrm{~min}$, 100 to $20 \%$ in $0.5 \mathrm{~min}$. The temperature of the column was maintained at $28^{\circ} \mathrm{C}$ during the run, and the flow rate was $1 \mathrm{~mL} / \mathrm{min}$. The absorbance was measured at $280 \mathrm{~nm}$ and $214 \mathrm{~nm}$. The whey protein standards were $\beta$-LG, $\alpha-\mathrm{LA}$, and CMP. The injection volume was 20 
$\mu \mathrm{L}$. The peaks were integrated, and the ratio $\mathrm{C}_{\mathrm{t}} / \mathrm{C}_{0}$ was plotted against the heating time, where $\mathrm{C}_{t}$ is the residual amount of native whey proteins at a time point $\mathrm{t}$ between 0 and $30 \mathrm{~min}$, and $\mathrm{C}_{0}$ the initial amount of native whey proteins. The rate of denaturation was estimated to be the slope of the tangent line along the first 5 min of heating, during which the amount of native whey proteins decreased the most. The amount of denatured and subsequently aggregated protein after 30-min heating was also reported. A typical chromatogram obtained after mixing whey protein and CMP is shown in Figure 2B.

\section{Differential Scanning Calorimetry}

For the DSC measurements, 20 to $30 \mathrm{mg}$ of sample were placed into an aluminum pan and heated in parallel to an empty reference pan. Despite the starting concentration of the samples being relatively low $(2.5 \%$, wt/vol), the denaturation peak of $\beta-\mathrm{LG}$ could still be identified, whereas the denaturation peak for $\alpha$-LA could not be identified in this study. The DSC used for this experiment was a DSC Q2000 (TA Instrument, Newcastle, DE) equipped with a refrigerator and a computer. The thermograms were analyzed using the TA Universal Analysis software (TA Instrument). The temperature of denaturation of $\beta-\mathrm{LG}$ at $\mathrm{pH} 3$ was not tested, as measurements using RP-HPLC showed no loss of native $\beta-\mathrm{LG}$ and formation of aggregates after heating for $30 \mathrm{~min}$ at $80^{\circ} \mathrm{C}$.

\section{Attenuated Total Reflection-Fourier-Transform Infrared Spectroscopy}

Measurements using FTIR were carried out before and after heating, using a Tensor 27 instrument (Bruker Corp., Billerica, MA) equipped with a thermally controlled attenuated total reflection cell BioATRcell II (Harrick Scientific, Pleasantville, NY). An average of 120 scans per sample were taken. Spectra were analyzed using the OPUS 7.5 software (Bruker) after atmosphere compensation, vector normalization, and substraction to non-heated samples or samples containing whey proteins only. At $\mathrm{pH}$ 3, the whey proteins exhibited very little denaturation and aggregation after heating; therefore this condition was not tested here.

\section{Turbidity and $\zeta$-Potential}

The turbidity of the samples was measured in polystyrene micro-cuvettes in a standard UV/vis-spectrophotometer at $20^{\circ} \mathrm{C}$. Turbidity was expressed as optical density (OD) at $600 \mathrm{~nm}$. At $\mathrm{pH} 3$, the whey proteins exhibited very little denaturation and aggregation af- ter heating; therefore this condition was not presented here.

The $\zeta$-potential of each sample was measured before and after heating for $30 \mathrm{~min}$. The $\zeta$-potential was determined using a Zetasizer Nano ZS (Malvern Instruments, Worcestershire, UK). Measurements were carried out at $20^{\circ} \mathrm{C}$ after an equilibration time of $120 \mathrm{~s}$ at room temperature. The refractive index and the viscosity of the dispersant were assumed the same as those of water; that is, 1.330 and $1.0031 \mathrm{cP}$, respectively. The attenuation values were between 5 and 11 . After heating at $\mathrm{pH}$ 5 , all samples exhibited microscopic aggregation during heating, and the $\zeta$-potential could not be measured.

\section{Molecular Weight Distribution}

The molecular weight distribution of the aggregates was measured by size-exclusion chromatography on a HPLC system (e2695, Waters Alliance, Milford, MA) equipped with a UV/visible detector (2489, Waters Alliance) and the analysis software Empower (Waters Alliance). Two columns in series, TSKgel G2000SW $\mathrm{XL}$ and TSKgel G3000SW $\mathrm{XL}_{\mathrm{XL}}$ (Tosoh Bioscience GmbH, Griesheim, Germany) with a guard column were used for the separation and analysis of the proteins. The dimension of the columns was $7.8 \times 300 \mathrm{~mm}$ each, and the exclusion volume was equivalent to $5 \times 10^{5}$ Da. The absorbance was recorded at $280 \mathrm{~nm}$. The buffer was $20 \mathrm{~m} M$ sodium phosphate ( $\mathrm{pH} 7.0$ ). The flow rate was $0.5 \mathrm{~mL} / \mathrm{min}$, and the total duration of each run was $60 \mathrm{~min}$. The coefficient of partition was calculated for the standards (thyroglobulin, aldolase, BSA, $\beta-\mathrm{LG}$, and $\alpha-\mathrm{LA})$ and the whey protein aggregates using the elution volume of blue dextran $\left(2 \times 10^{6} \mathrm{Da}\right)$ as exclusion volume.

\section{Atomic Force Microscopy}

Whey proteins and d-CMP aggregates were imaged via atomic force microscopy (AFM) using an Asylum Research MFP-3DAFM (Oxford, UK) in AC mode, as previously described (Kehoe et al., 2011). All samples were diluted to $0.1 \%$ protein (wt/vol) and deposited onto a freshly cleaved mica surface. The samples were subsequently dried in a desiccator. Images were processed using AFM imaging software Igor 6.12A (Wavemetrics, Portland, OR) and Argyle Light (Asylum Research, Goleta, CA) for 3-dimensional images.

\section{Statistical Analysis}

All measurements were taken in at least 3 independent replicates. The DSC and FTIR measurements were done in 2 independent replicates, due to the higher 
protein concentrations required for these experiments and the limited sample availability after the enzymatic treatment. The distribution of the rates of denaturation and the turbidity were presented as medians, with quartiles and whiskers representing, respectively, the 25th and 75th mark and the minimum and maximum values. Percentage of denatured proteins, $\zeta$-potential and molecular weight distribution and peak temperature of denaturation were presented as the mean $\pm \mathrm{SD}$.

\section{RESULTS AND DISCUSSION}

\section{Denaturation of $\beta-L G$ and $\alpha-L A$ in the Presence of CMP and d-CMP}

At temperatures greater than $60^{\circ} \mathrm{C}$, whey proteins are known to unfold, exposing their hydrophobic sites and making the thiol groups accessible for new intra- and intermolecular interactions. This results in irreversible aggregation of whey proteins, which is strongly dependent on the heating conditions. In their native forms, $\beta$-LG and $\alpha$-LA are soluble at all $\mathrm{pH}$ values, including at their pI, respectively 5.1 and 4.2 to 4.5 (Eigel et al., 1984). Denaturation and aggregation of whey proteins causes their precipitation at pH 4.6 (Okuda and Zoller, 1921). This allowed measurement of the native proteins during heating, via precipitation of the denatured and subsequently aggregated proteins at $\mathrm{pH} 4.6$, and thus, estimation of denaturation rates in the very early stage of heating. The denaturation rates of $\beta-L G$ and $\alpha-\mathrm{LA}$ - that is, the estimated rates of denaturation in the first 5 min of heating - are presented in Figure 3. The amounts of denatured $\alpha$-LA and $\beta$-LG after $30 \mathrm{~min}$ heating are presented in Figure 4. The temperature of denaturation, at which half of the $\beta-\mathrm{LG}$ in the samples has lost its native conformation, was measured using DSC and presented in Table 1.

As expected, due to its unordered, flexible, and highly stable structure (Smith et al., 2002), CMP did not exhibit denaturation at any $\mathrm{pH}$ tested (results not shown). Both $\beta$-LG and $\alpha$-LA had higher rates of denaturation at $\mathrm{pH} 5$ than at any other $\mathrm{pH}$, with over $88 \%$ (wt/wt) of $\beta-\mathrm{LG}$ and $66 \%$ (wt/wt) of $\alpha-\mathrm{LA}$ denatured after 30-min heating at $\mathrm{pH} 5.0$, regardless of protein composition and concentration (Figure 3 and 4). In contrast, at $\mathrm{pH} 3.0$, little denaturation of whey proteins was observed after 30-min heating (Figure 4). Stable particles of partially unfolded whey proteins from $\mathrm{pH}$ 2.5 were previously observed (Harwalkar, 1980). However, for experimental conditions used in this study, only native proteins could be measured by RP-HPLC, as explained above (Kehoe et al., 2011). Therefore, if any changes in conformation happened to the whey proteins during heating at $\mathrm{pH} 3$ in this study, these modifications had to be reversible to be undetectable by RP-HPLC. Moreover, Verheul et al. (1998) found a decrease of the initial reaction rate and an increase in the temperature of denaturation of $\beta-\mathrm{LG}$ when the protein was heated at $\mathrm{pH} 3$, which supports our findings and suggests that the heating temperature in this study may have been below the temperature of denaturation of whey proteins.

Above $\mathrm{pH} 4, \alpha$-LA had generally a lower rate of denaturation and a lower relative amount of denatured material than $\beta$-LG (Figures 3 and 4). This agrees with previous studies reporting $\beta$-LG's greater sensitivity to denaturation compared with $\alpha-\mathrm{LA}$ (Law and Leaver, 2000). However, at $\mathrm{pH} \mathrm{4}$, and in particular in the presence of CMP or d-CMP, the denaturation rate of $\alpha$-LA was higher (Figure 3), regardless of the protein composition and concentration of the samples, than that of $\beta$-LG. Although the conformation of proteins is more stable around their pI (4.2 to 4.5 for $\alpha$-LA), non-covalent interactions are promoted, resulting in greater precipitation of $\alpha$-LA. A higher protein content (1\%, wt/vol, whey protein) also favored $\alpha$-LA denaturation, as reported in previous studies (Hillier et al., 1979), which could be another reason for the greater rate of denaturation of $\alpha$-LA in the presence of CMP or d-CMP (Figure 3). The presence of CMP or d-CMP resulted in a lower temperature of denaturation (Table 1) and a greater amount of denatured $\beta$-LG after $30-$ min heating at $\mathrm{pH} 4$ than the results of $0.5 \%$ (wt/ vol) whey protein only (Figure 4). However, CMP had a stronger effect on the rate of denaturation of $\beta$-LG at $\mathrm{pH} 4$ compared with d-CMP (Figure 3). At $\mathrm{pH} 4$, $\beta-\mathrm{LG}$ is positively charged; however, CMP is strongly negatively charged, whereas d-CMP is close to its $\mathrm{pI}$ (3.7). Thus, the attractive electrostatic interactions are stronger with CMP than with d-CMP, leading to faster denaturation of $\beta$-LG. A greater decrease of the $\zeta$-potential before heating was observed for the mixture containing $0.5 \%$ (wt/vol) whey proteins with CMP, which could be a result of the attractive interactions between the whey proteins and CMP or an average of their respective $\zeta$-potentials at $\mathrm{pH} 4$ (Figure $5 \mathrm{~A}$ ). Previous authors found that CMP and $\beta-L G$ interacted at $\mathrm{pH} 3.5$ to form aggregates from few nanometers to $1 \mu \mathrm{m}$ in diameter before heating, most likely via electrostatic interactions or hydrogen bonding (Martinez et al., 2010). Changes in the secondary structure of the unheated proteins upon addition of CMP or d-CMP are presented in Figure 6. At $\mathrm{pH} 4$, a decrease around $1,655 \mathrm{~cm}^{-1}$ indicated a loss of $\alpha$-helix and disordered structures in the mixture of whey proteins and CMP or d-CMP, compared with the sample containing whey proteins only (Barth, 2007). Bovine $\beta-\mathrm{LG}$ and $\alpha$-LA have 8 and $26 \%$ of $\alpha$-helix, and $47 \%$ and $60 \%$ of ran- 
$\alpha-\mathbf{L A}$

A

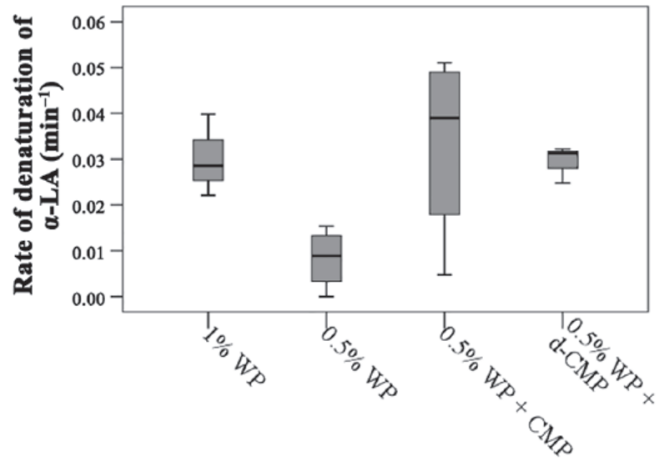

$\mathrm{C}$

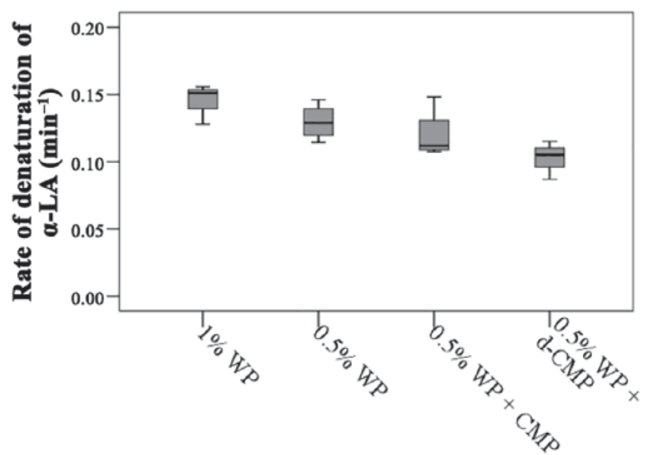

$\mathrm{E}$

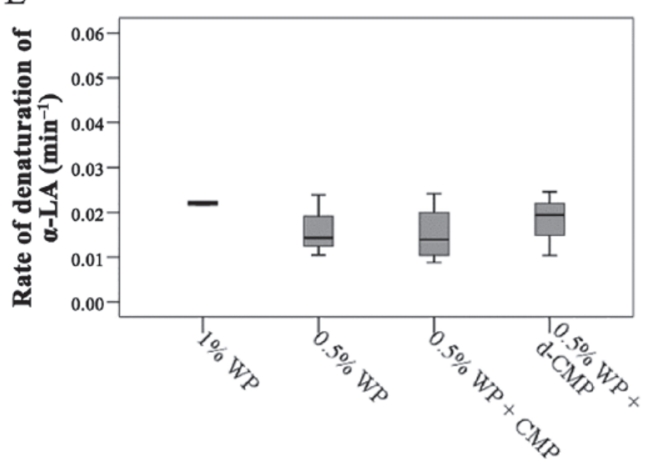

$\mathrm{G}$

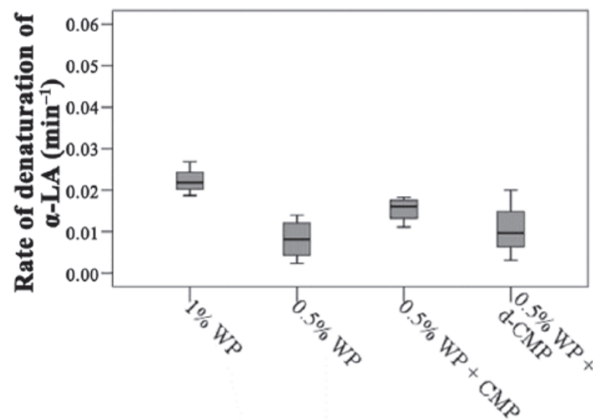

B-LG
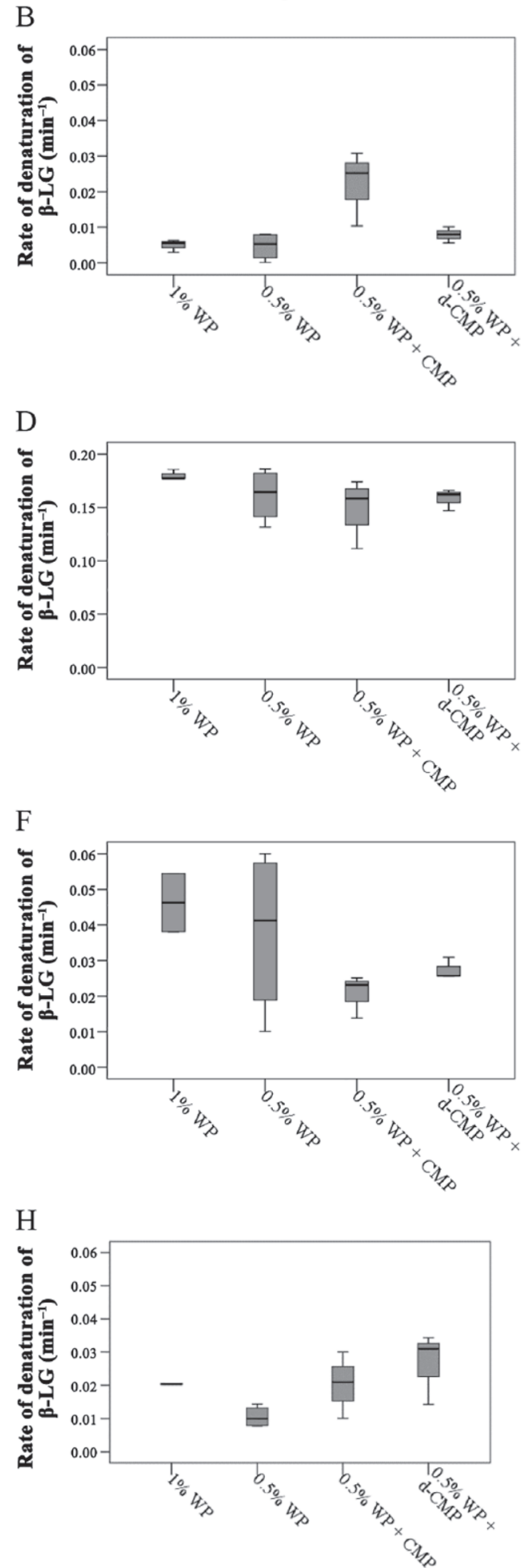

Figure 3. Rates of denaturation per minute of $\alpha$-LA (panels A, C, E, and G) and $\beta$-LG (panels B, D, F, and H) in the first 5 min of heating at $80^{\circ} \mathrm{C}$ at $\mathrm{pH} 4(\mathrm{~A}, \mathrm{~B}), 5(\mathrm{C}, \mathrm{D}), 6(\mathrm{E}, \mathrm{F})$, and $7(\mathrm{G}, \mathrm{H})$ of $1 \%(\mathrm{wt} / \mathrm{vol}$ ) whey protein $(\mathrm{WP})$ solution, $0.5 \%$ (wt/vol) WP solution, a mixture of $0.5 \%$ (wt/vol) WP and caseinomacropeptide (CMP), and a mixture of $0.5 \%$ (wt/vol) WP and desialylated CMP (d-CMP). Experimental points are the average of data from at least 3 independent trials. Results are presented as medians, with quartiles and whiskers representing the 25 th and 75 th mark and the minimum and maximum values, respectively. Figure 4 shows that the whey proteins exhibited very little denaturation and aggregation after heating at $\mathrm{pH} 3$ for $30 \mathrm{~min}$ at $80^{\circ} \mathrm{C}$; therefore the rates of denaturation of $\alpha$ - $\mathrm{LA}$ and $\beta$-LG at $\mathrm{pH} 3.0$ are not presented here. 
Table 1. Temperature of denaturation $\left({ }^{\circ} \mathrm{C}\right)$ of $\beta$-LG by differential scanning calorimetry (DSC) for samples containing 2.5 to $5 \%$ (wt/vol) whey proteins (WP) and a mixture of $2.5 \%$ (wt/vol) WP and caseinomacropeptide $(\mathrm{CMP})$ or desialylated CMP (d-CMP $)^{1}$

\begin{tabular}{lcccc}
\hline & \multicolumn{5}{c}{$\mathrm{pH}$} \\
\cline { 2 - 5 } Item & 4 & 5 & 6 & 7 \\
\hline $5 \% \mathrm{WP}$ & $87.5 \pm 0.0$ & $80.3 \pm 0.2$ & $79.8 \pm 0.1$ & $77.8 \pm 0.1$ \\
$2.5 \% \mathrm{WP}$ & $88.3 \pm 0.3$ & $80.2 \pm 0.2$ & $80.9 \pm 0.1$ & $73.2 \pm 0.5$ \\
$2.5 \% \mathrm{WP}+\mathrm{CMP}$ & $85.0 \pm 0.5$ & $82.4 \pm 0.4$ & $81.3 \pm 0.0$ & $77.0 \pm 0.2$ \\
$2.5 \% \mathrm{WP}+$ d-CMP & $86.3 \pm 0.8$ & $83.6 \pm 0.2$ & $82.1 \pm 0.4$ & $75.1 \pm 1.0$ \\
\hline
\end{tabular}

${ }^{1}$ Samples were heated up to $100^{\circ} \mathrm{C}$, at $\mathrm{pH} 4$ to 7 , and the heating rate was $5^{\circ} \mathrm{C} / \mathrm{min}$. The temperature of denaturation of $\beta$-LG at $\mathrm{pH} 3$ was not tested, as previous measurements (Figure 4) showed that $\beta$-LG did not denature after heating for $30 \mathrm{~min}$ at $80^{\circ} \mathrm{C}$. Experimental points are the average of data from 2 independent trials \pm SD.

dom coils in their native forms, respectively (Deeth and Bansal, 2018). Caseinomacropeptide was reported to be mainly disordered, with little secondary structure, and its glycosylation has very little effect on the secondary structure (Smith et al., 2002). Therefore, the change in secondary structure at $\mathrm{pH} 4$ before heating could be

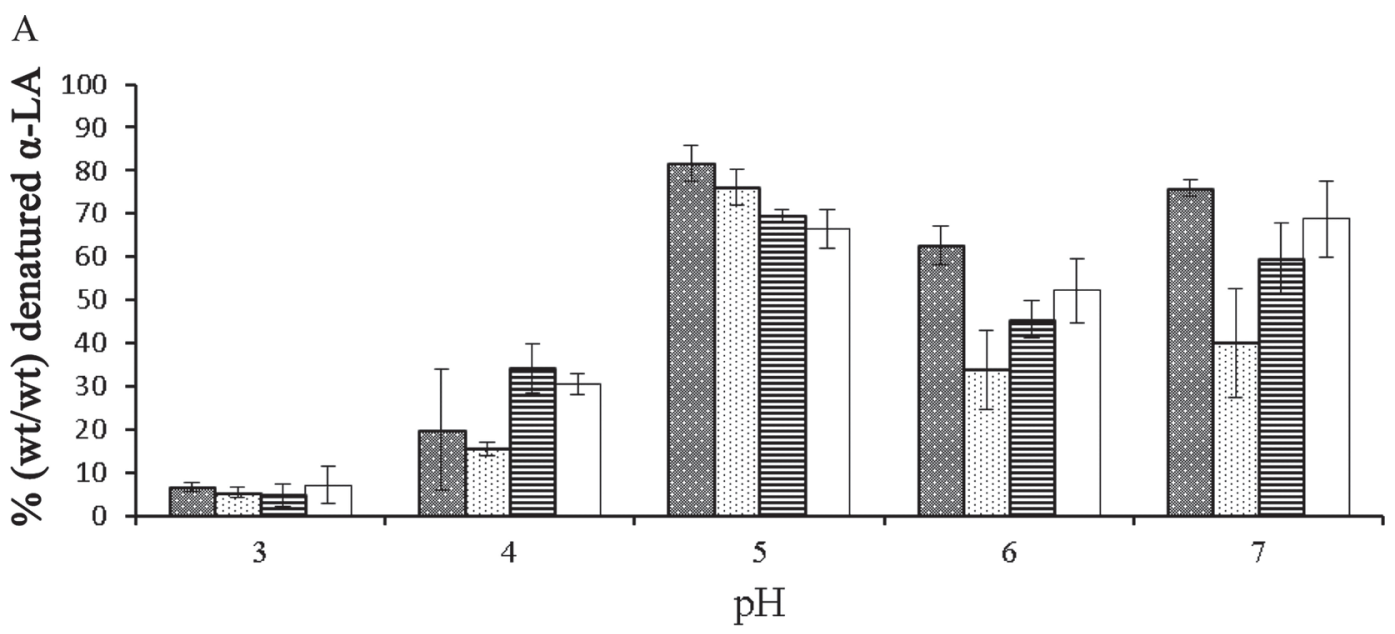

B

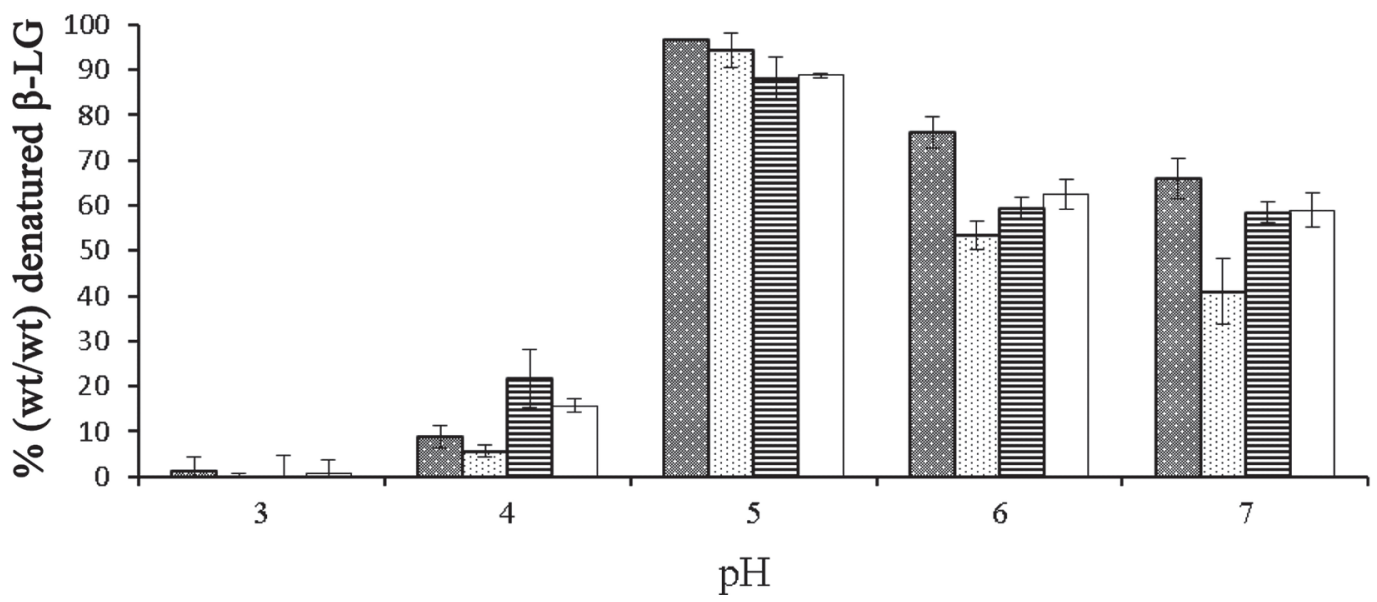

Figure 4. Percentage of denatured $\alpha$-LA (A) and $\beta$-LG (B) after heating 1\% (wt/vol) whey protein (WP, dark dotted bars), $0.5 \%$ (wt/vol) WP (light dotted bars), a mixture of $0.5 \%$ (wt/vol) WP and caseinomacropeptide (CMP, horizontal striped bars), and a mixture of $0.5 \%$ (wt/ vol) WP and desialylated CMP (d-CMP, open bars) at $80^{\circ} \mathrm{C}$ for 30 min after adjustment at pH 3, 4, 5, 6, and 7. The annotation "wt/wt" refers to weight of denatured protein per total of the corresponding protein. Experimental points are the average of data from at least 3 independent trials, and error bars correspond to SD. 
A

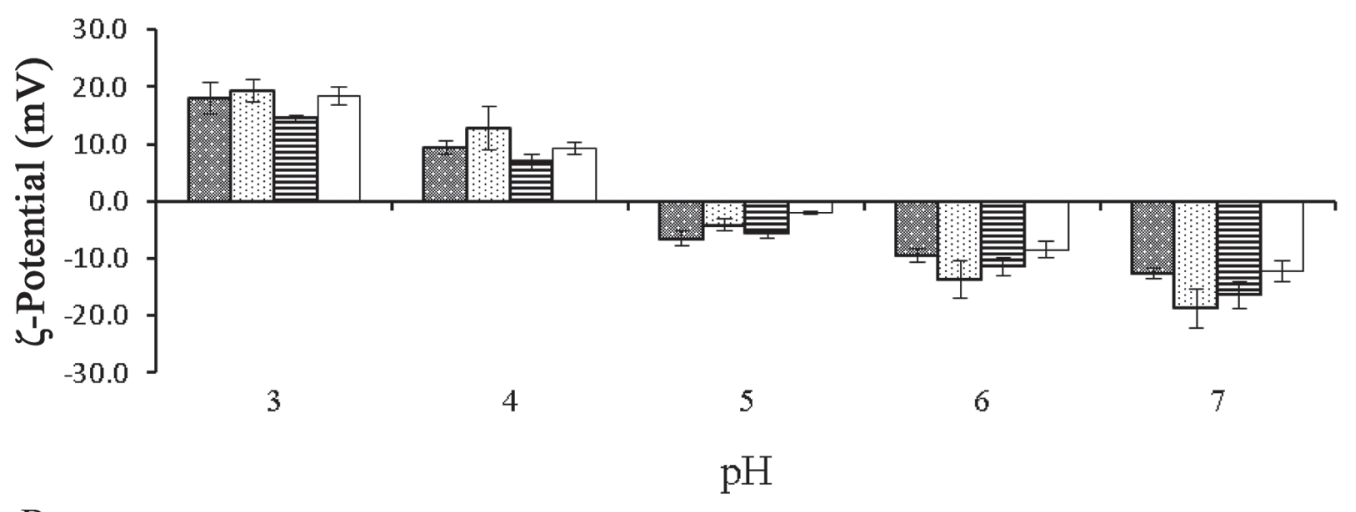

B

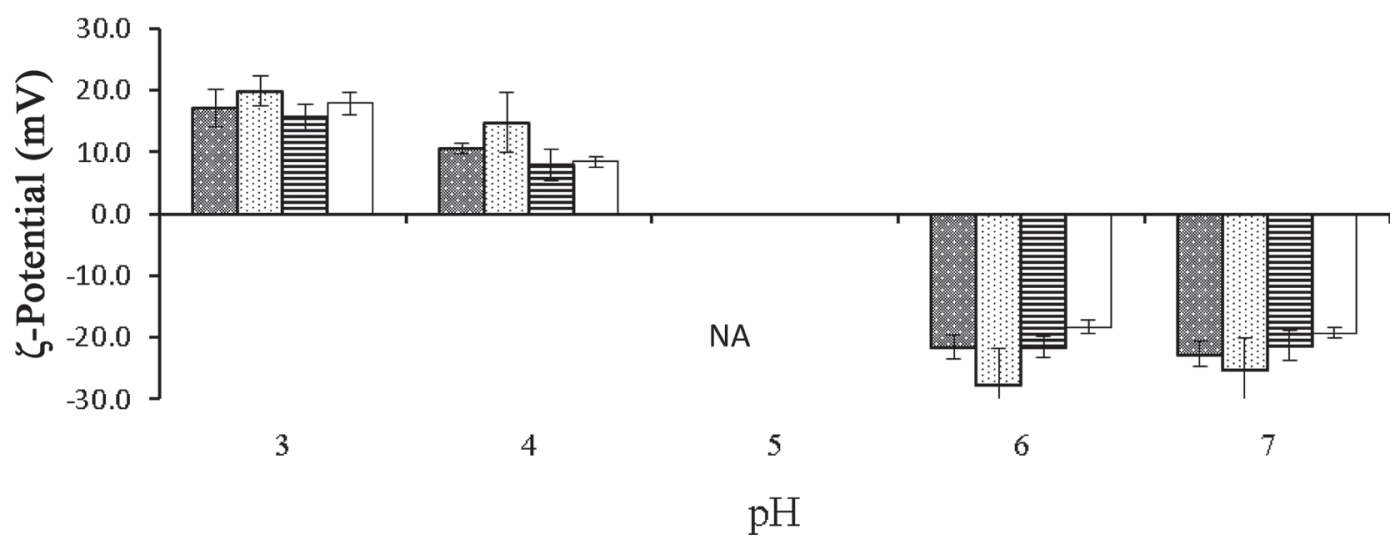

Figure 5. $\zeta$-Potential of $1 \%$ (wt/vol) whey protein (WP) solution (dark dotted bars), $0.5 \%$ (wt/vol) WP solution (light dotted bars), a mixture of $0.5 \%$ (wt/vol) WP and caseinomacropeptide (CMP, horizontal striped bars), and a mixture of $0.5 \%$ (wt/vol) WP and desialylated CMP

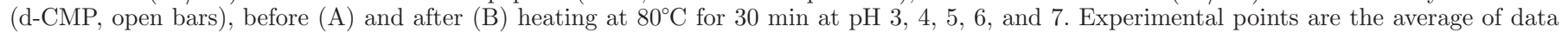
from at least 3 independent trials, and error bars correspond to SD. NA indicates that the samples exhibited microscopic aggregation during heating and no measurements were taken.

attributed to either the whey proteins or the CMP, or both, and provides evidence for interactions between whey proteins and CMP or d-CMP before heating. Our results showing a higher rate of denaturation of the whey proteins in the presence of CMP (Figure 3) and a greater extent of denaturation in presence of CMP or d-CMP (Figure 4) were in agreement with recent studies highlighting that the temperature for the onset of denaturation and the temperature of denaturation of $\beta-\mathrm{LG}$ decreased with the ratio of $\beta-\mathrm{LG}$ to CMP at pH 3.5 (Martinez et al., 2010) and the denaturation of $\beta$-LG accelerated in the presence of $\mathrm{CMP}$ at $\mathrm{pH} 4.0$ (Croguennec et al., 2014).

At $\mathrm{pH} 5, \beta-\mathrm{LG}$ was very close to its native $\mathrm{pI}$ of 5.2 , and its global surface charge was minimal, which promoted non-covalent aggregation. Under these circumstances, the rate of denaturation and the amount of denatured $\beta-\mathrm{LG}$ were higher than those of $\alpha-\mathrm{LA}$ (Figures 3 and 4 ). The rates of denaturation of $\beta-\mathrm{LG}$ and $\alpha$-LA were lowered at $\mathrm{pH} 5$ and 6 in the presence of
CMP or d-CMP (Figure 3), with the exception of $\alpha$-LA in the presence of $\mathrm{d}-\mathrm{CMP}$ and at $\mathrm{pH}$ 6. These lower rates of denaturation could be caused by the stabilization of the whey proteins by additional electrostatic repulsion provided by CMP or d-CMP. These results are supported by a higher temperature of denaturation of $\beta-\mathrm{LG}$ at $\mathrm{pH}$ greater than 4 in the presence of CMP or d-CMP (Table 1). The $\zeta$-potential was closer to 0 in $0.5 \%$ (wt/vol) whey protein sample in the presence of d-CMP than in the presence of CMP at $\mathrm{pH} 5$ (Figure $5 \mathrm{~A}$ ). This could be the average of the surface charges of the peptide and the whey proteins, or the proteins could interact more readily through attractive electrostatic and possibly hydrophobic interactions when the sialic acid NeuAc was removed. At pH 5 and 6, the temperature of denaturation of $\beta-\mathrm{LG}$ in the presence of d-CMP was higher than that in the presence of CMP (Table 1). Haque and Khalifa (1992) found that the hydrophobicity of $\kappa$-casein fractions decreased with their content of NeuAc. In addition, the glycosylation of CMP caused 
steric hindrance, electrostatic repulsion, and less hydrophobic interaction, which prevented interaction with oil at the interface of emulsions (Kreuß et al., 2009). Therefore, the highly negatively charged glycosylation of CMP may prevent hydrophobic interactions by increasing the electrostatic repulsions between CMP and whey proteins. The negative charges carried by the amino acids and the negatively charged phosphorylated residues of d-CMP could also have contributed to the stability of the whey proteins on their own. Koudelka et al. (2009) showed that the phosphorylated residues, the amphipathic nature, and the flexibility of $\alpha_{\mathrm{S1}^{-}}$and $\beta$-caseins are key features of their chaperone activity on proteins.

At $\mathrm{pH} 5$, the amount of denatured whey proteins after $30 \mathrm{~min}$ of heating in the presence of d-CMP was reduced compared with that of $0.5 \%$ (wt/vol) whey protein only (Figure 4). However, at $\mathrm{pH} 6$, the stabilization of $\beta$-LG by d-CMP was effective only in the initial stage of heating (up to $5 \mathrm{~min}$ ), and the amount of denatured $\beta$-LG increased after 30-min heating with
d-CMP (Figures 3 and 4). The conformation of whey proteins is more stable at $\mathrm{pH}$ values close to their $\mathrm{pI}$ and less stable at $\mathrm{pH}$ greater than 5 , due to increased intramolecular repulsion leading to unfolding and increased reactivity of the thiol groups (Hoffmann and van Mil, 1997). This was illustrated by a decrease of the temperatures of denaturation (Table 1) for all samples at $\mathrm{pH}$ greater than 4 . Thus, although the presence of d-CMP initially stabilized the native conformation of $\beta$-LG, the interactions between $\beta$-LG and d-CMP were affected by the heat-induced unfolding of the whey proteins and the formation of new intermolecular disulfide bonds, and promoted the denaturation of $\beta-\mathrm{LG}$ on prolonged heating at $\mathrm{pH}$ 6. Croguennec et al. (2014) also observed that $\mathrm{pH}$ affected the heat-induced interactions between CMP and $\beta$-LG with a stabilizing effect on the native conformation of $\beta$-LG at $\mathrm{pH} 4.0$ and a destabilizing effect at $\mathrm{pH}$ 6.7. The mixture of whey proteins and d-CMP had a lower $\zeta$-potential than the sample with $0.5 \%$ (wt/vol) whey protein only at $\mathrm{pH} 6$ (Figure 5A), which could be due to greater electrostatic interactions
A

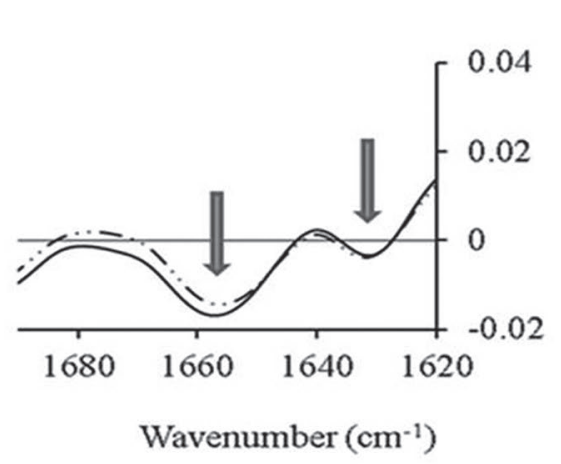

$\mathrm{C}$

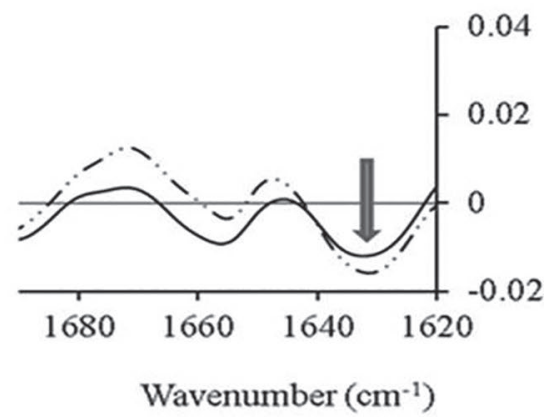

B

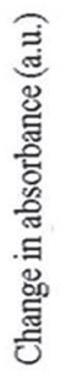

D

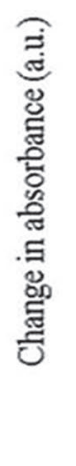

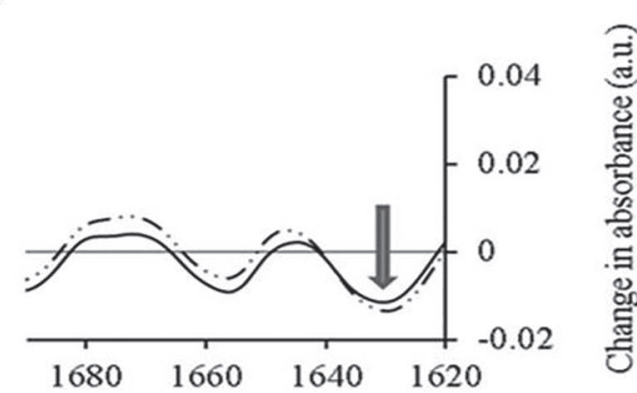

Wavenumber $\left(\mathrm{cm}^{-1}\right)$

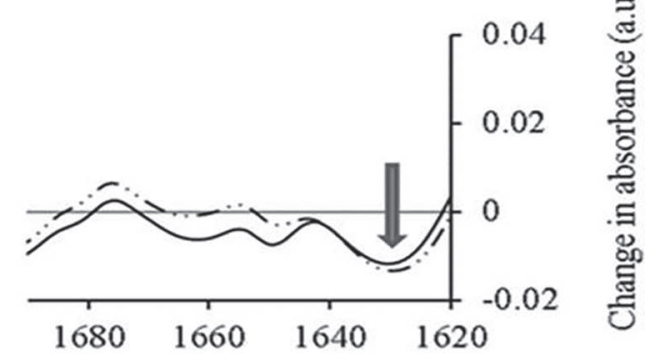

Wavenumber $\left(\mathrm{cm}^{-1}\right)$

Figure 6. Attenuated total reflectance-Fourier-transform infrared spectroscopy (ATR-FTIR) spectra of amide I bands of non-heated samples at $\mathrm{pH} 4(\mathrm{~A}), 5(\mathrm{~B}), 6(\mathrm{C})$, and 7 (D) containing $2.5 \%$ (wt/vol) whey proteins (WP) with caseinomacropeptide (CMP, solid line) or 2.5\% (wt/ vol) WP with desialylated CMP (d-CMP, dotted and dashed line), with the spectra of the non-heated solution of $2.5 \%$ (wt/vol) WP substracted. Arrows highlight deviations in the region $1,655 \mathrm{~cm}^{-1}$ and $1,630 \mathrm{~cm}^{-1}$ upon addition of CMP or d-CMP from the whey protein solutions, represented by a horizontal line through the origin in each panel. Experimental points are the average of data from 2 independent trials. FTIR measurements were carried out on samples exhibiting some protein denaturation after heating for 30 min at $80^{\circ} \mathrm{C}$. At $\mathrm{pH} 3$, whey proteins exhibited very little denaturation and aggregation after heating; therefore this condition was not tested here (see Figure 4). 
A

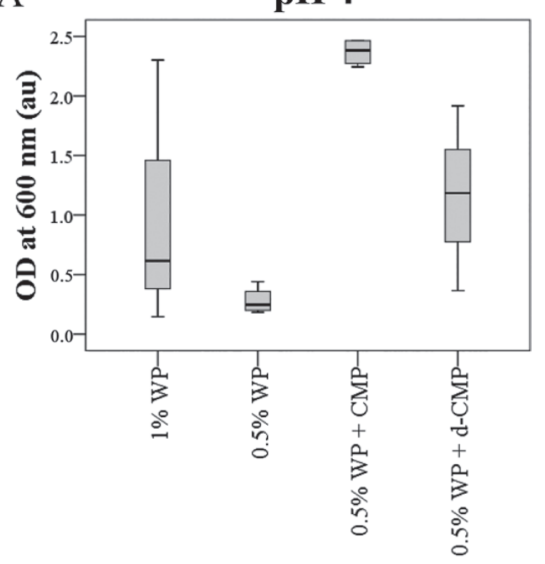

B

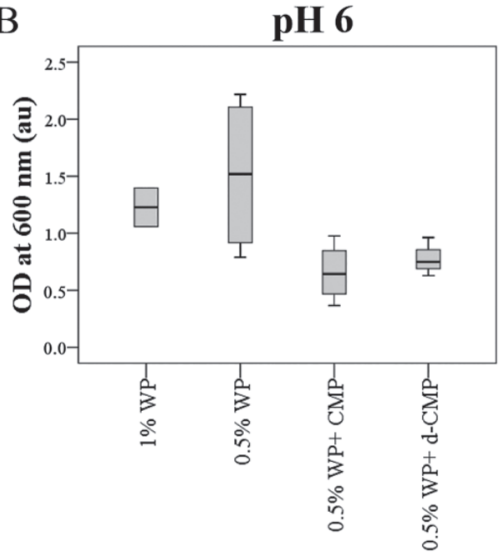

C

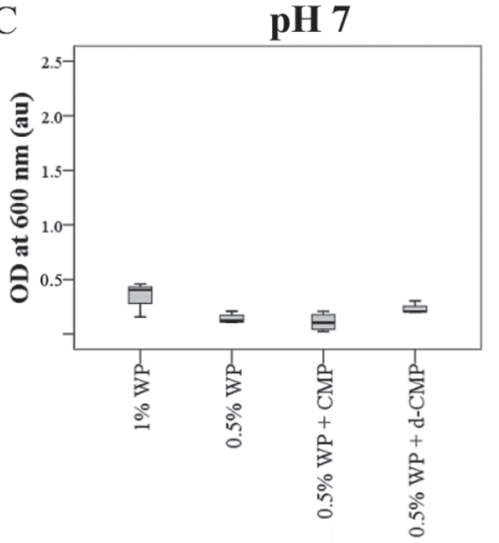

Figure 7. Turbidity expressed as optical density (OD) at $600 \mathrm{~nm}$ of $1 \%$ (wt/vol) whey proteins (WP) solution, $0.5 \%$ (wt/vol) WP solution, a mixture of $0.5 \%$ (wt/vol) WP and caseinomacropeptide (CMP), and a mixture of $0.5 \%$ (wt/vol) WP and desialylated CMP (d-CMP) after heating at $80^{\circ} \mathrm{C}$ for $30 \mathrm{~min}$ at $\mathrm{pH} 4(\mathrm{~A}), 6$ (B), and 7 (C). Results are presented as medians, with quartiles and whiskers representing, respectively, the 25 th and 75 th mark and the minimum and maximum values. Experimental points are the average of data from at least 3 independent trials. All samples displayed microscopic aggregates at $\mathrm{pH} 5$ after a few minutes of heating, and measurements could not be taken. At $\mathrm{pH} 3$, the whey proteins exhibited very little denaturation and aggregation after heating (see Figure 4); therefore the results at this $\mathrm{pH}$ condition are not presented here.

1

2 3

A

pH 4

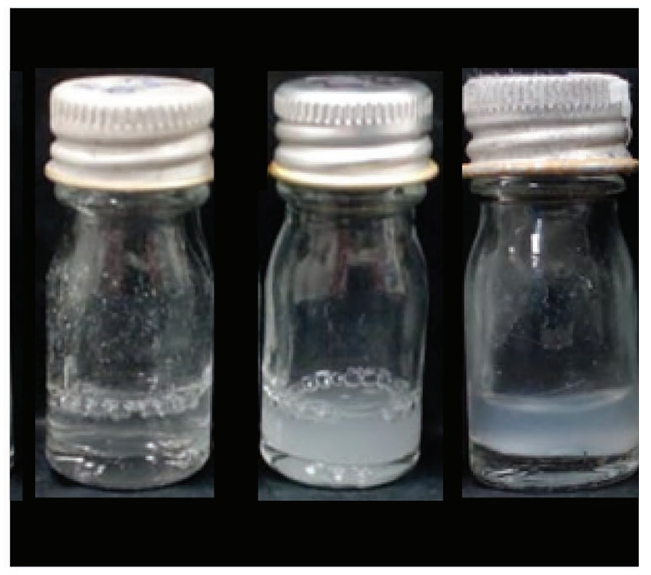

B

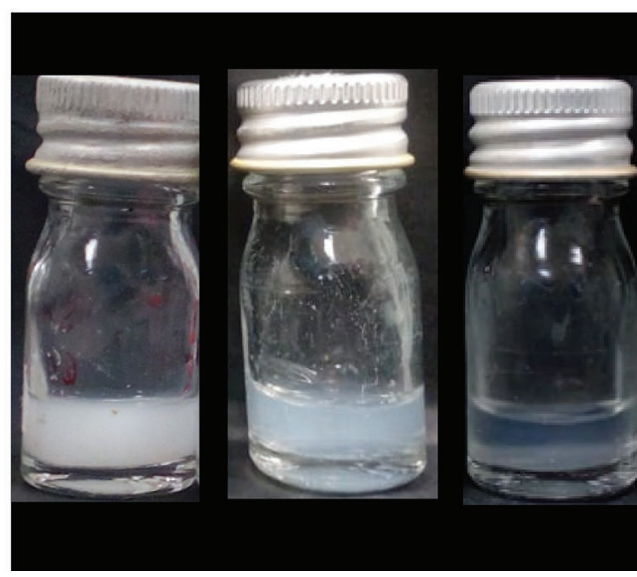

Figure 8. Photographs of a solution of $0.5 \%$ (wt/vol) whey protein (WP, 1), a mixture of $0.5 \%$ (wt/vol) WP and caseinomacropeptide (CMP, 2), and a mixture of $0.5 \%$ (wt/vol) WP and desialylated CMP (d-CMP, 3) after heating at $80^{\circ} \mathrm{C}$ for $30 \mathrm{~min}$ at $\mathrm{pH} 4(\mathrm{~A})$ and $6(\mathrm{~B})$.

or could be the average of the $\zeta$-potentials of all proteins in solution. However, interactions between CMP or dCMP and the whey proteins above $\mathrm{pH} 5$ were evident from a strong decrease in the intramolecular $\beta$-sheet signal (Figure 6) around 1,630 $\mathrm{cm}^{-1}$. This contrasts with the changes in secondary structure obtained at $\mathrm{pH}$ 4 , where a loss of $\alpha$-helix or random coil structure was observed (Figure 6) and highlights the effect of $\mathrm{pH}$ on the nature of the interaction between the whey proteins and CMP or d-CMP.

At $\mathrm{pH}$ 7, CMP and, more particularly, d-CMP promoted the denaturation of $\beta$-LG (Figures 3 and 4). Thus, from this method based on the precipitation of the aggregates at their pI, we found no evidence for stabilization of the whey proteins, even during the initial stages of heating. In contrast, the denaturation temperature of $\beta$-LG (i.e., the temperature measured 
A

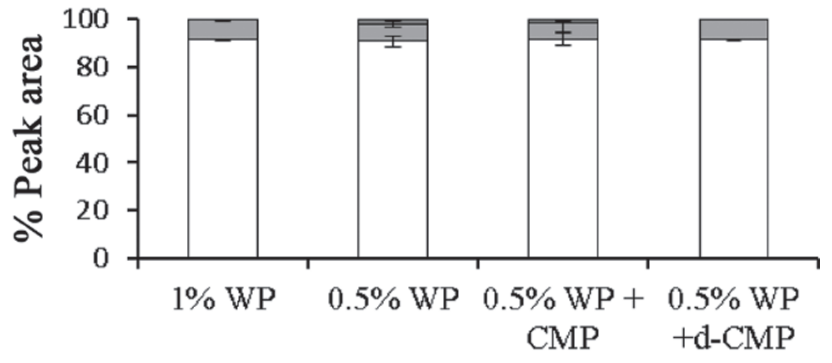

B

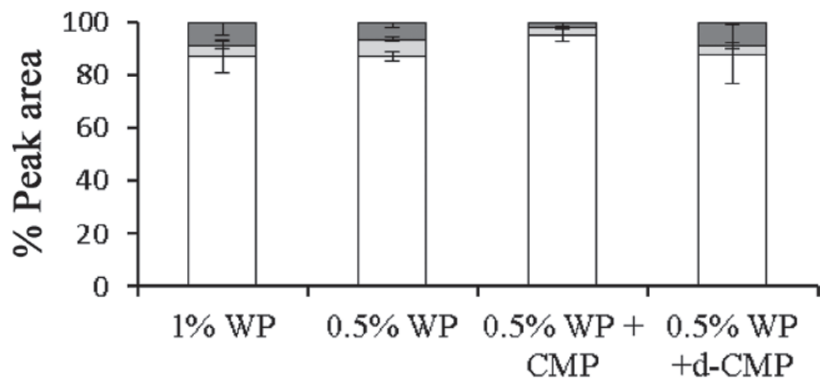

$\mathrm{C}$

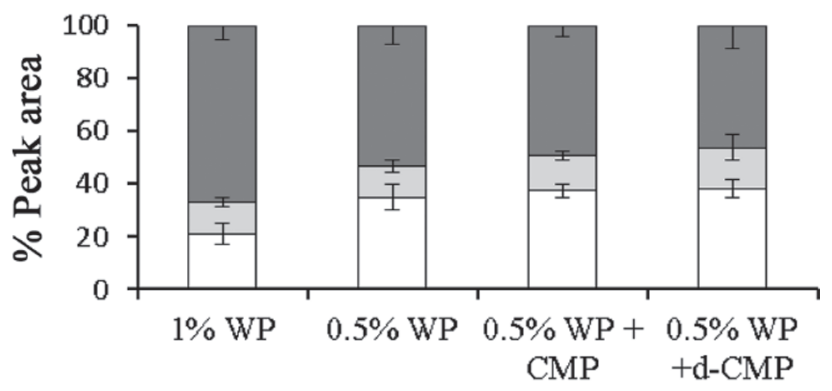

$\mathrm{D}$

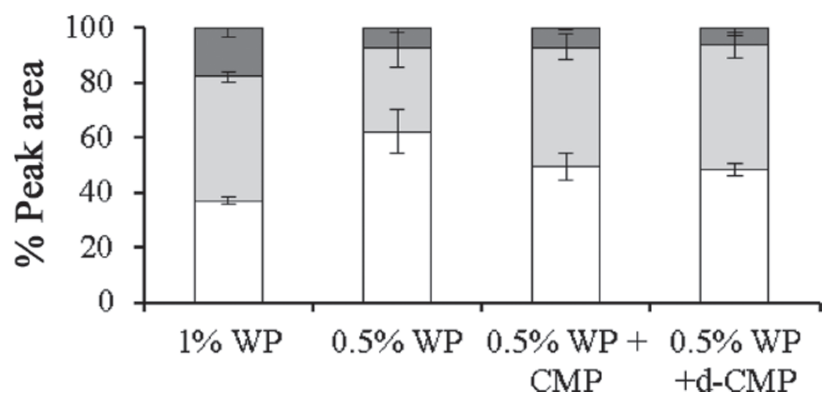

Figure 9. Molecular weight distribution of soluble whey proteins (WP) by size-exclusion chromatography in $1 \%$ (wt/vol) WP solution, $0.5 \%$ (wt/vol) WP solution, a mixture of $0.5 \%$ (wt/vol) WP and caseinomacropeptide (CMP), and a mixture of $0.5 \%$ (wt/vol) WP and desialylated CMP (d-CMP) after heating at $80^{\circ} \mathrm{C}$ for $30 \mathrm{~min}$ at $\mathrm{pH} 3.0$ (A), 4.0 (B), 6.0 (C), and 7.0 (D). Distribution represented as follows: unshaded portion $=8$ to $60 \mathrm{kDa}$, light shaded portion $=60$ to 500 $\mathrm{kDa}$, and dark shaded portion $=>500 \mathrm{kDa}$. Experimental points are the average of data from at least 3 independent trials, and error bars correspond to SD. All samples displayed microscopic aggregates at $\mathrm{pH}$ 5 after a few minutes of heating at $80^{\circ} \mathrm{C}$, and most of the aggregates formed during heating were filtered out through $0.45-\mu \mathrm{m}$ hydrophilic filters; therefore the results are not presented here. by DSC at which $50 \%$ of $\beta-\mathrm{LG}$ is denatured) was higher in the presence of CMP or d-CMP at $\mathrm{pH} 7$ (Table 1). However, the denaturation temperature of $\beta$-LG heated in the presence of d-CMP was close to that of the control containing $0.5 \%$ (wt/vol) whey protein only. Therefore, the sialic acid hindered the denaturation of $\beta-\mathrm{LG}$ at $\mathrm{pH}$ 7 , and its removal resulted in lower electrostatic interactions, which could have facilitated the hydrophobic interactions between d-CMP and the unfolded $\beta$-LG. Other authors have previously demonstrated the role of hydrophobic and electrostatic interactions in stabilizing the native conformation of $\beta-L G$ in the presence of peptides from hydrolyzed whey proteins (Barbeau et al., 1996). The higher charge density of the peptides and the hydrophobic interactions of $\beta$-LG with the peptides were assumed to induce a more compact form of $\beta$-LG. Above $\mathrm{pH} 6.8$, the protective effect of the negatively charged peptides was lower, which is in agreement with our results. Other authors emphasized that CMP accelerated the denaturation rate of $\beta-\mathrm{LG}$ and promoted the unfolding of $\beta-\mathrm{LG}$ at $\mathrm{pH} 6.7$ due to an increase in negative charges, which destabilizes the native state of $\beta$-LG (Croguennec et al., 2014), concluding that CMP interaction is stronger with the unfolded form of $\beta$-LG than with the compact native form. In addition, Martinez et al. (2009) reported a decrease in the temperature of denaturation and the onset temperature of denaturation of $\beta$-LG measured by DSC in the presence of CMP. However, other authors found that CMP increased the temperature of denaturation when $\beta$-LG was heated with other whey proteins (Svanborg et al., 2016). These results could be explained by differences in the composition of the starting materials.

The presence of CMP or d-CMP did not affect the early stage of denaturation of $\alpha-\mathrm{LA}$ at $\mathrm{pH}$ greater than 5 to the same extent that it affected the early denaturation of $\beta$-LG (Figure 3). The differences in chemical composition between the 2 whey proteins, in particular the absence of a free thiol group on $\alpha-\mathrm{LA}$ and the ability of $\beta$-LG to bind small hydrophobic molecules, could explain the differences observed (Muresan et al., 2001).

\section{Aggregation Behavior of Whey Proteins in the Presence of CMP or $d-C M P$}

Figures 7 and 8 present the turbidity of the protein solutions after heating at $80^{\circ} \mathrm{C}$ for $30 \mathrm{~min}$, and Figure 9 illustrates the molecular weight distribution of the samples after heating. The OD at $600 \mathrm{~nm}$ was a sensitive indicator of the extent of whey protein aggregation (Li et al., 2019).

As expected, the proteins did not form large aggregates at $\mathrm{pH} 3$ (Figure 9A). At $\mathrm{pH} 5$, the turbidity increased greatly within 2 min of heating, due to a 
A

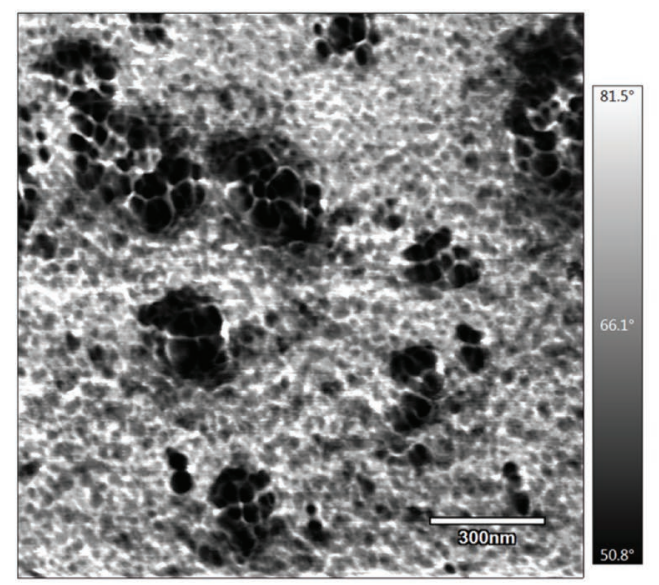

$\mathrm{B}$

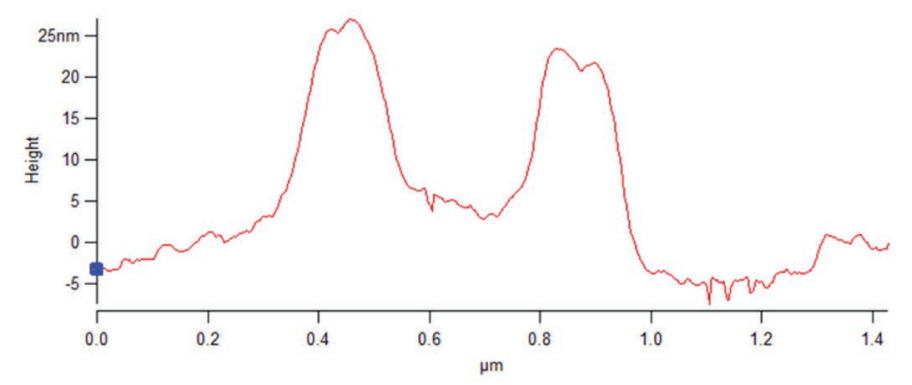

$\mathrm{C}$

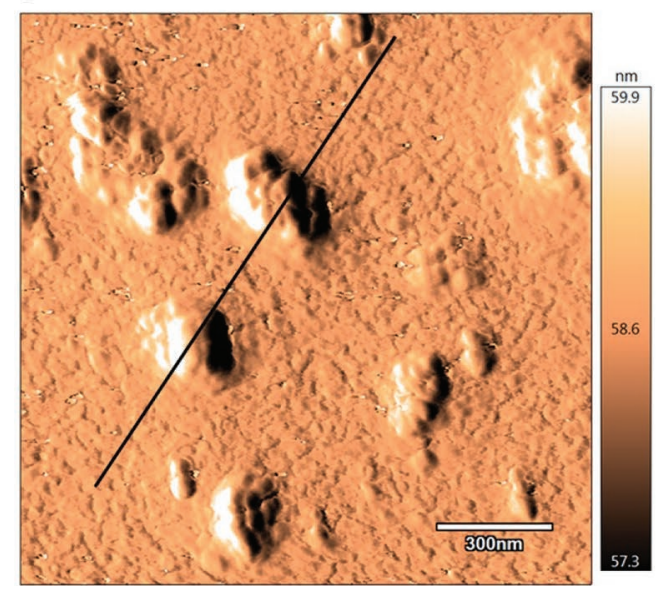

Figure 10. Atomic force microscopy images showing phase (A), height across the cross-section marked in the 3-dimensional height image (B), and amplitude for a representative sample of $0.5 \%$ (wt/vol) whey proteins and desialylated caseinomacropeptide $(\mathrm{C})$ after heating at $80^{\circ} \mathrm{C}$ for $30 \mathrm{~min}$ at $\mathrm{pH} 6$.

greater instability of $\beta$-LG during heating, as electrostatic repulsion was at its minimum around its $\mathrm{pI}$ (results not shown). All samples gelled after $30 \mathrm{~min}$ of heating at $\mathrm{pH} 5$. At $\mathrm{pH} 4$ and within 5 min of heating, the samples containing CMP developed a higher turbidity than the samples containing only whey proteins
(Figures 7A and 8A). The greater extent of aggregation at this $\mathrm{pH}$ could be the result of attractive electrostatic interactions between the whey proteins and CMP. Most of those aggregates were likely removed after filtration through $0.45-\mu \mathrm{m}$ filters, before size-exclusion chromatography; very few aggregates greater than $500 \mathrm{kDa}$ were present in the filtrate (Figure 9B), which is in contradiction with the high turbidity developed in the samples containing CMP (Figure 7A). At $\mathrm{pH}$ 4, the aggregates in the samples containing CMP presented a higher turbidity than the ones in the samples heated at $\mathrm{pH}$ greater than 5 (Figure 7A), although the amount of denatured protein was lower (Figure 4). Croguennec et al. (2014) observed the formation of aggregates with diameter greater than $5 \mu \mathrm{m}$ and a phase separation in a solution of $\beta-\mathrm{LG}$ and CMP heated at $\mathrm{pH}$ 4.0.

At $\mathrm{pH} 6$, the largest aggregates were formed when $1 \%$ (wt/vol) whey protein was heated on its own (Figure $9 \mathrm{C})$. This is in agreement with the higher amount of denatured protein (Figure 4) and the high OD of the samples after 30-min heating (Figure 7B). The OD was much lower in the samples containing CMP or d-CMP (Figures $7 \mathrm{~B}$ and $8 \mathrm{~B}$ ). The amount of denatured $\beta$-LG in the samples containing CMP or d-CMP at $\mathrm{pH} 6$ was higher than in that containing $0.5 \%$ (wt/vol) whey protein only (Figure 4). This confirmed that the effect of CMP and d-CMP on the denaturation of the whey proteins also affected the aggregation behavior of the whey proteins. In spite of the interactions between $\beta$-LG and CMP or d-CMP leading to more denatured $\beta$-LG after $30 \mathrm{~min}$ of heating, its stabilization within the first $5 \mathrm{~min}$ of heating could have had a durable effect on the structure of the aggregates. An example of a 3-dimensional AFM image of the aggregates of whey proteins and d-CMP at pH 6 is presented in Figure 10. The height across section (Figure 10B) shows that the aggregates are polydisperse, with sizes ranging from 5 to $20 \mathrm{~nm}$. High-resolution phase and amplitude images (Figures 10A and $\mathrm{C}$ ) show that the aggregates consist of individual monomers of proteins, presumably $\beta$-LG.

At $\mathrm{pH} 7$, the $\mathrm{OD}$ and the aggregate size range were lower than at $\mathrm{pH} 6$ for all samples (Figures 7 and 9). The OD of the samples containing $0.5 \%$ whey protein, with or without CMP or d-CMP, were very close (Figure 7C). However, the relative amount of medium-size aggregates was lower, and the relative amounts of monomers, dimers, or trimers smaller than $60 \mathrm{kDa}$ were higher in $0.5 \%$ (wt/vol) whey protein than in the samples containing d-CMP (Figure 9D). This is in agreement with more denatured $\beta$-LG being measured in the samples containing d-CMP (Figure 4) and can be explained by stronger interactions between the whey proteins in the presence of d-CMP. It was previously reported that, at $\mathrm{pH}$ 7.0, the heat-induced gelation of $\beta-\mathrm{LG}$ would 
occur only in the presence of CMP, whereas a solution of $\beta$-LG on its own would not gel, at least not under the experimental conditions of this study (Martinez et al., 2010); the authors highlighted that the temperature required for gelation of the protein systems was lowered in the presence of CMP. In contrast, Croguennec et al. (2014) found smaller particle sizes of aggregates and decreased turbidity after heating $\beta$-LG at $\mathrm{pH} 6.7$ in the presence of CMP, although the corresponding activation energy in the aggregation-limited temperature range (above $80^{\circ} \mathrm{C}$ ) decreased in the presence of CMP. Both of these studies hypothesized that the negative charges of $\beta-\mathrm{LG}$ and CMP around $\mathrm{pH} 7$ destabilized the native form of $\beta$-LG. The main difference between the studies was the resulting type of protein gel. This could be due to the variations in heating conditions and starting materials. Overall, the differences in molecular weight of the aggregates were minor at $\mathrm{pH} 7$ in the present study.

A

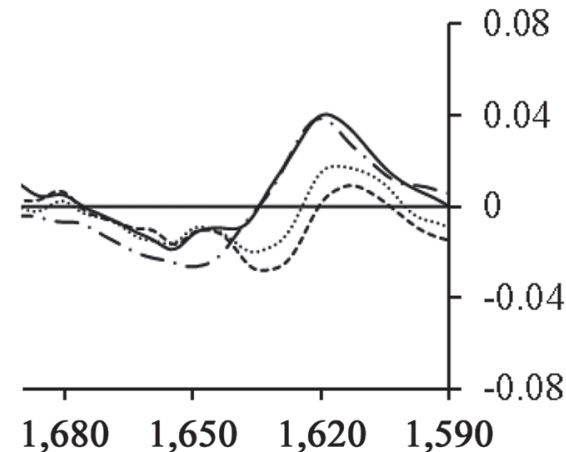

$\mathrm{C}$

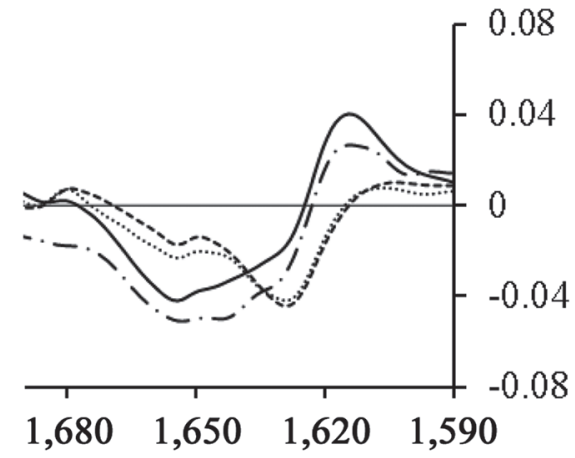

Wavenumber $\left(\mathrm{cm}^{-1}\right)$
After heating, all aggregates formed in solutions at $\mathrm{pH}$ greater than 5 , with or without CMP, exhibited a more negative $\zeta$-potential (Figure $5 \mathrm{~B}$ ). This is a welldocumented effect of heating on whey proteins (Ryan et al., 2012; Kehoe and Foegeding, 2014). The changes in secondary structure of the proteins after heating give further insight on the effect of CMP or d-CMP on whey protein aggregation as a function of $\mathrm{pH}$ (Figure 11). As previously explained, the changes in $\beta$-sheets are mainly attributed to $\beta-\mathrm{LG}$ and $\alpha-\mathrm{LA}$, containing respectively 45 and $14 \% \beta$-sheets in their native form (Deeth and Bansal, 2018). Intramolecular $\beta$-sheets absorb around $1,630 \mathrm{~cm}^{-1}$, and the heat-induced formation of intermolecular $\beta$-sheets causes a shift in their absorption to $1.620 \mathrm{~cm}^{-1}$ (Lefèvre and Subirade, 2000; Kehoe et al., 2008). From pH 4 to 6 , the presence of CMP or d-CMP prevented the formation of intermolecular $\beta$-sheets in heat-induced aggregates. At $\mathrm{pH}$ 7, CMP or d-CMP did not prevent the formation of intermolecular $\beta$-sheets

B

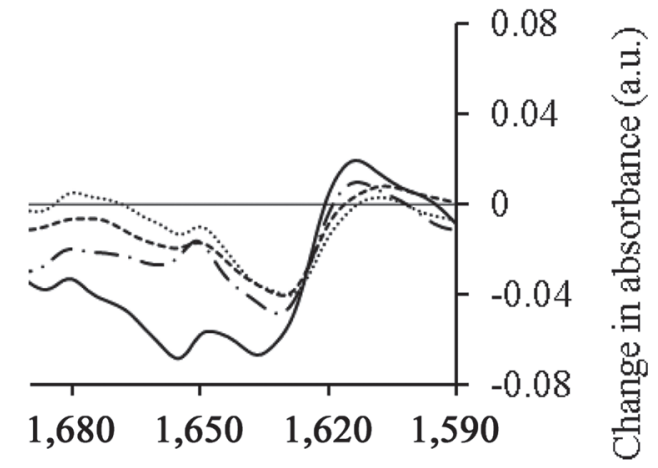

D

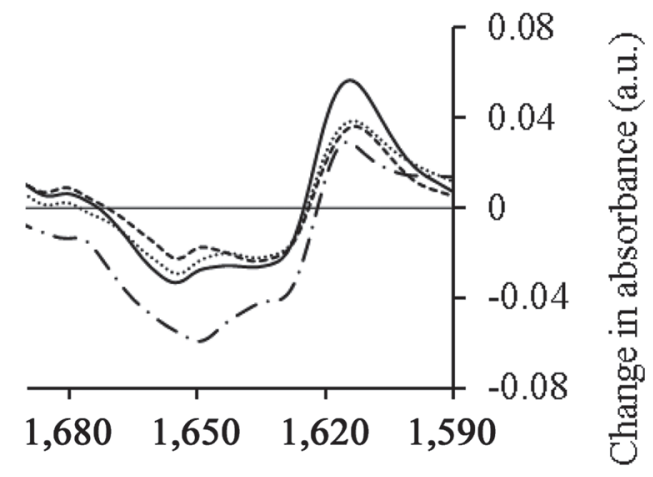

Wavenumber $\left(\mathrm{cm}^{-1}\right)$

Figure 11. Attenuated total reflectance-Fourier-transform infrared spectroscopy (ATR-FTIR) spectra of amide I bands of heated samples at $\mathrm{pH} 4(\mathrm{~A}), 5(\mathrm{~B}), 6(\mathrm{C})$, or 7 (D) containing 5\% (wt/vol) whey proteins (WP, solid line), 2.5\% (wt/vol) WP (dashed-dotted line), $2.5 \%$ (wt/ vol) WP with caseinomacropeptide (CMP, dashed line) or $2.5 \%$ (wt/vol) WP with desialylated CMP (d-CMP, dotted line), with the spectra of the corresponding non-heated samples substracted. The horizontal line through the origin in each panel highlights deviations in the spectra upon heating. Samples were heated at $\mathrm{pH} 4,5,6$, or 7 for $30 \mathrm{~min}$ at $80^{\circ} \mathrm{C}$ and at $\mathrm{pH} 5$ for 5 min. Experimental points are the average of data from 2 independent trials. FTIR measurements were carried out on samples exhibiting some protein denaturation after heating for 30 min at $80^{\circ} \mathrm{C}$. At pH 3, WP exhibited very little denaturation and aggregation after heating; therefore this condition was not tested here (see Figure 4). 
(Figure 11), which is consistent with the rate of denaturation and denatured material results (Figures 3 and $4)$.

\section{CONCLUSIONS}

The desialylation of CMP modified the electrostatic interactions between the peptide and major whey proteins $\beta$-LG and $\alpha$-LA during heating as a function of $\mathrm{pH}$. Above the $\mathrm{pI}$ of the proteins, the removal of the sialic acid facilitated interactions between CMP and the major whey proteins, particularly $\beta$-LG, likely through enhanced hydrophobic interactions. The presence of CMP led to a greater extent of denaturation and aggregation of the whey proteins when they were heated at around neutral $\mathrm{pH}$ (i.e., $\mathrm{pH}$ favoring their unfolding). In the initial stages of heating and at $\mathrm{pH} 5$ to 6 (i.e., near their pI), the whey proteins were in a more stable conformation, and the interactions with CMP enhanced the stability of the whey proteins against denaturation and aggregation. These results contribute to a better understanding of the mechanism of interaction between the major whey proteins and CMP. Advantage should be taken of this knowledge and the innate CMP content of cheese whey to enhance the heat stability of whey proteins. In particular, any pre-processes resulting in the loss of sialic acid are likely to affect the heat-induced denaturation and aggregation of whey proteins.

\section{ACKNOWLEDGMENTS}

This work was supported by Dairy Levy Research Trust (project MDDT6261 "ProPart"). S. J. Gaspard was funded under the Teagasc Walsh Fellowship Scheme (reference number 2012211; Fermoy, Ireland). A. V. Sunds was funded by Aarhus University Research Foundation (AUFF) and the Graduate School of Science and Technology (GSST) at Aarhus University, Aarhus, Denmark. The authors have not stated any conflicts of interest.

\section{REFERENCES}

Barbeau, J., S. F. Gauthier, and Y. Pouliot. 1996. Thermal stabilization of $\beta$-lactoglobulin by whey peptide fractions. J. Agric. Food Chem. 44:3939-3945. https://doi.org/10.1021/jf960081b.

Barth, A. 2007. Infrared spectroscopy of proteins. Biochim. Biophys. Acta 1767:1073-1101.

Beyer, H. J., and H. G. Kessler. 1989. Bestimmung des thermischen Denaturierungverhaltens von Molkenproteinen HPLC. GIT Suppl. Lebensmittel 2:22-26.

Brody, E. P. 2000. Biological activities of bovine glycomacropeptide. Br. J. Nutr. 84(Suppl. 1):S39-S46. https://doi.org/10.1017/ S0007114500002233.
Cases, E., V. Vidal, and J. Cuq. 2003. Effect of к-casein deglycosylation on the acid coagulability of milk. J. Food Sci. 68:2406-2410. https://doi.org/10.1111/j.1365-2621.2003.tb07037.x.

Croguennec, T., N. Leng, P. Hamon, F. Rousseau, R. Jeantet, and S. Bouhallab. 2014. Caseinomacropeptide modifies the heat-induced denaturation-aggregation process of $\beta$-lactoglobulin. Int. Dairy J. 36:55-64. https://doi.org/10.1016/j.idairyj.2014.01.004.

Deeth, H. C., and N. Bansal. 2018. Whey Proteins: From Milk to Medicine. Academic Press, Amsterdam, the Netherlands.

Doi, H., F. Ibuki, and M. Kanamori. 1981. Effect of carbohydrate moiety of $\kappa$-casein on the complex formation with $\beta$-lactoglobulin. Agric. Biol. Chem. 45:2351-2353. https://doi.org/10.1271/bbb1961 .45 .2351 .

Eigel, W. N., J. E. Butler, C. A. Ernstrom, H. M. Farrell Jr., V. R. Harwalkar, R. Jenness, and R. M. Whitney. 1984. Nomenclature of proteins of cow's milk: Fifth revision. J. Dairy Sci. 67:1599-1631. https://doi.org/10.3168/jds.S0022-0302(84)81485-X.

Guyomarc'h, F., M. Nono, T. Nicolai, and D. Durand. 2009. Heatinduced aggregation of whey proteins in the presence of $\kappa$-casein or sodium caseinate. Food Hydrocoll. 23:1103-1110. https://doi.org/ 10.1016/j.foodhyd.2008.07.001.

Haque, Z. U., and M. Y. Khalifa. 1992. k-Casein heterogeneity and mild heating effects on susceptibility to chymosin action. J. Food Sci. 57:49-54. https://doi.org/10.1111/j.1365-2621.1992.tb05422 .x.

Harwalkar, V. R. 1980. Kinetics of thermal denaturation of 3-lactoglobulin at pH 2.5. J. Dairy Sci. 63:1052-1057. https://doi .org/10.3168/jds.S0022-0302(80)83046-3.

Hillier, R. M., R. L. Lyster, and G. C. Cheeseman. 1979. Thermal denaturation of $\alpha$-lactalbumin and $\beta$-lactoglobulin in cheese whey: Effect of total solids concentration and pH. J. Dairy Res. 46:103111. https://doi.org/10.1017/S0022029900016903.

Hoffmann, M. A. M., and P. J. J. M. van Mil. 1997. Heat-induced aggregation of $\beta$-lactoglobulin: Role of the free thiol group and disulfide bonds. J. Agric. Food Chem. 45:2942-2948. https://doi .org/10.1021/jf960789q.

Holland, J. W. 2008. Post-translational modifications of caseins. Pages 107-132 in Milk Proteins. Elsevier, Amsterdam, the Netherlands.

Huppertz, T. 2013. Chemistry of the caseins. Pages 135-160 in Advanced Dairy Chemistry. Springer, New York, NY.

Karman, A. H., and M. A. J. S. Van Boekel. 1986. Evaluation of the Kjeldahl factor for conversion of the nitrogen content of milk and milk products to protein content. Neth. Milk Dairy J. 40:315-336.

Kehoe, J. J., and E. A. Foegeding. 2014. The characteristics of heatinduced aggregates formed by mixtures of $\beta$-lactoglobulin and $\beta$-casein. Food Hydrocoll. 39:264-271. https://doi.org/10.1016/j .foodhyd.2014.01.019.

Kehoe, J. J., G. E. Remondetto, M. Subirade, E. R. Morris, and A. Brodkorb. 2008. Tryptophan-mediated denaturation of $\beta$-lactoglobulin A by UV irradiation. J. Agric. Food Chem. 56:4720-4725. https:/ /doi.org/10.1021/jf0733158.

Kehoe, J. J., L. Wang, E. R. Morris, and A. Brodkorb. 2011. Formation of non-native $\beta$-lactoglobulin during heat-induced denaturation. Food Biophys. 6:487-496. https://doi.org/10.1007/s11483 -011-9230-3.

Kilic-Akyilmaz, M., and A. Karimidastjerd. 2018. Impact of the order of acid and heat treatments on the composition of caseinomacropeptide isolate. Int. Dairy J. 82:45-50. https://doi.org/10.1016/j .idairyj.2018.02.008.

Koudelka, T., P. Hoffmann, and J. A. Carver. 2009. Dephosphorylation of $\alpha_{\mathrm{s}^{-}}$and $\beta$-caseins and its effect on chaperone activity: A structural and functional investigation. J. Agric. Food Chem. 57:5956-5964. https://doi.org/10.1021/jf9008372.

Kreuß, M., T. Strixner, and U. Kulozik. 2009. The effect of glycosylation on the interfacial properties of bovine caseinomacropeptide. Food Hydrocoll. 23:1818-1826. https://doi.org/10.1016/j.foodhyd .2009.01.011.

Law, A. J., and J. Leaver. 2000. Effect of $\mathrm{pH}$ on the thermal denaturation of whey proteins in milk. J. Agric. Food Chem. 48:672-679. https://doi.org/10.1021/jf981302b. 
Le, T. T., S. D. Nielsen, N. S. Villumsen, G. H. Kristiansen, L. R. Nielsen, S. B. Nielsen, M. Hammershøj, and L. B. Larsen. 2016. Using proteomics to characterise storage-induced aggregates in acidic whey protein isolate drinks. Int. Dairy J. 60:39-46. https:// doi.org/10.1016/j.idairyj.2016.01.028.

Lefèvre, T., and M. Subirade. 2000. Molecular differences in the formation and structure of fine-stranded and particulate $\beta$-lactoglobulin gels. Biopolymers 54:578-586. https://doi.org/10.1002/1097 -0282(200012)54:7<578::AID-BIP100>3.0.CO;2-2.

Li, M., M. A. E. Auty, S. V. Crowley, A. L. Kelly, J. A. O'Mahony, and A. Brodkorb. 2019. Self-association of bovine $\beta$-casein as influenced by calcium chloride, buffer type and temperature. Food Hydrocoll. 88:190-198. https://doi.org/10.1016/j.foodhyd.2018.09 .035 .

Martinez, M. J., M. E. Farías, and A. M. R. Pilosof. 2010. The dynamics of heat gelation of casein glycomacropeptide- $\beta$-lactoglobulin mixtures as affected by interactions in the aqueous phase. Int. Dairy J. 20:580-588. https://doi.org/10.1016/j.idairyj.2009.11 .016 .

Martinez, M. J., C. C. Sanchez, J. M. Patino, and A. M. Pilosof. 2009 Interactions in the aqueous phase and adsorption at the air-water interface of caseinoglycomacropeptide (GMP) and $\beta$-lactoglobulin mixed systems. Colloids Surf. B Biointerfaces 68:39-47. https:// doi.org/10.1016/j.colsurfb.2008.09.006.

Morgan, P. E., T. M. Treweek, R. A. Lindner, W. E. Price, and J. A. Carver. 2005. Casein proteins as molecular chaperones. J. Agric. Food Chem. 53:2670-2683. https://doi.org/10.1021/jf048329h.

Muresan, S., A. van der Bent, and F. A. de Wolf. 2001. Interaction of $\beta$-lactoglobulin with small hydrophobic ligands as monitored by fluorometry and equilibrium dialysis: Nonlinear quenching effects related to protein - protein association. J. Agric. Food Chem. 49:2609-2618. https://doi.org/10.1021/jf0012188.

Nagel, B., H. Dellweg, and L. Gierasch. 1992. Glossary for chemists of terms used in biotechnology (IUPAC recommendations 1992). Pure Appl. Chem. 64:143-168. https://doi.org/10.1351/ pac199264010143.

O'Riordan, N., M. Kane, L. Joshi, and R. M. Hickey. 2014. Structural and functional characteristics of bovine milk protein glycosylation. Glycobiology 24:220-236. https://doi.org/10.1093/glycob/cwt162.

Okuda, Y., and H. F. Zoller. 1921. The relations of hydrogen-ion concentration to the heat coagulation of proteins in Swiss cheese whey. J. Ind. Eng. Chem. 13:515-519. https://doi.org/10.1021/ ie50138a008.

Ryan, K. N., B. Vardhanabhuti, D. P. Jaramillo, J. H. van Zanten, J. N. Coupland, and E. A. Foegeding. 2012. Stability and mechanism of whey protein soluble aggregates thermally treated with salts. Food Hydrocoll. 27:411-420. https://doi.org/10.1016/j.foodhyd 2011.11.006

Saito, T., and T. Itoh. 1992. Variations and distributions of O-glycosidically linked sugar chains in bovine $\kappa$-casein. J. Dairy Sci.
75:1768-1774. https://doi.org/10.3168/jds.S0022-0302(92)77936 $-3$.

Siegert, N., A. Tolkach, and U. Kulozik. 2012. The pH-dependent thermal and storage stability of glycosylated caseinomacropeptide. Lebensm. Wiss. Technol. 47:407-412. https://doi.org/10.1016/j .lwt.2012.02.001.

Smith, M. H., P. J. Edwards, K. P. Palmano, and L. K. Creamer. 2002. Structural features of bovine caseinomacropeptide A and B by ${ }^{1} \mathrm{H}$ nuclear magnetic resonance spectroscopy. J. Dairy Res. 69:85-94. https://doi.org/10.1017/S0022029901005271.

Sunds, A. V., N. A. Poulsen, and L. B. Larsen. 2019. Short communication: Application of proteomics for characterization of caseinomacropeptide isoforms before and after desialidation. J. Dairy Sci. 102:8696-8703. https://doi.org/10.3168/jds.2019-16617.

Svanborg, S., A.-G. Johansen, R. K. Abrahamsen, R. B. Schüller, and S. B. Skeie. 2016. Caseinomacropeptide influences the functional properties of a whey protein concentrate. Int. Dairy J. 60:14-23. https://doi.org/10.1016/j.idairyj.2015.12.007.

Taylor, C., and B. Woonton. 2009. Quantity and carbohydrate content of glycomacropeptide fractions isolated from raw and heat-treated milk. Int. Dairy J. 19:709-714. https://doi.org/10.1016/j.idairyj 2009.06.010.

Thomä, C., I. Krause, and U. Kulozik. 2006. Precipitation behaviour of caseinomacropeptides and their simultaneous determination with whey proteins by RP-HPLC. Int. Dairy J. 16:285-293. https: //doi.org/10.1016/j.idairyj.2005.05.003.

Thomä-Worringer, C., J. Sørensen, and R. López-Fandiño. 2006. Health effects and technological features of caseinomacropeptide. Int. Dairy J. 16:1324-1333. https://doi.org/10.1016/j.idairyj.2006 .06 .012 .

Tolkach, A., S. Steinle, and U. Kulozik. 2005. Optimization of thermal pretreatment conditions for the separation of native $\alpha$-lactalbumin from whey protein concentrates by means of selective denaturation of $\beta$-lactoglobulin. J. Food Sci. 70:E557-E566. https://doi.org/10 .1111/j.1365-2621.2005.tb08319.x.

Traving, C., and R. Schauer. 1998. Structure, function and metabolism of sialic acids. Cell. Mol. Life Sci. 54:1330-1349.

Varki, A. 2008. Sialic acids in human health and disease. Trends Mol. Med. 14:351-360. https://doi.org/10.1016/j.molmed.2008.06.002.

Verheul, M., S. P. F. M. Roefs, and K. G. de Kruif. 1998. Kinetics of heat-induced aggregation of $\beta$-lactoglobulin. J. Agric. Food Chem. 46:896-903. https://doi.org/10.1021/jf970751t.

Villumsen, N. S., H. B. Jensen, T. T. Thu Le, H. S. Møller, R. T. Nordvang, L. R. Nielsen, S. B. Nielsen, J. Sørensen, M. Hammershøj, and L. B. Larsen. 2015. Self-assembly of caseinomacropeptide as a potential key mechanism in the formation of visible storage induced aggregates in acidic whey protein isolate dispersions. Int. Dairy J. 49:8-15. https://doi.org/10.1016/j.idairyj.2015.05.003. 